\title{
The role of remote sensing in process-scaling studies of managed forest ecosystems
}

Jeffrey G. Masek ${ }^{1}$, Daniel J. Hayes ${ }^{2,3}$, M. Joseph Hughes ${ }^{3}$, Sean P. Healey ${ }^{4}$, David P. Turner $^{5}$

${ }^{1}$ Biospheric Sciences Laboratory (Code 618), NASA Goddard Space Flight Center, Greenbelt, MD

${ }^{2}$ Environmental Sciences Division, Oak Ridge National Laboratory, Oak Ridge, TN;

${ }^{3}$ Department of Ecology and Evolutionary Biology, University of Tenn., Knoxville, TN;

${ }^{4}$ USDA Forest Service, Rocky Mountain Research Station, Ogden, UT;

${ }^{5}$ Department of Forest Ecosystems and Society, Oregon State Univ., Corvallis, OR

Corresponding Author: Jeffrey Masek, NASA GSFC (Jeffrey.G.Masek@nasa.gov)

Manuscript in preparation for Forest Ecology and Management, special issue on

"Carbon, water and nutrient cycling in managed forests"

Draft 9, last updated: 7 May 2015 


\section{Abstract}

$4 \quad$ Sustaining forest resources requires a better understanding of forest ecosystem

5 processes, and how management decisions and climate change may affect these processes

6 in the future. While plot and inventory data provide our most detailed information on

7 forest carbon, energy, and water cycling, applying this understanding to broader spatial

8 and temporal domains requires scaling approaches. Remote sensing provides a powerful

9 resource for "upscaling" process understanding to regional and continental domains. The

10 increased range of available remote sensing modalities, including interferometric radar,

11 lidar, and hyperspectral imagery, allows the retrieval of a broad range of forest attributes.

12 This paper reviews the application of remote sensing for upscaling forest attributes from

13 the plot scale to regional domains, with particular emphasis on how remote sensing

14 products can support parameterization and validation of ecosystem process models. We

15 focus on four key ecological attributes of forests: composition, structure, productivity

16 and evapotranspiration, and disturbance dynamics. For each attribute, we discuss

17 relevant remote sensing technologies, provide examples of their application, and critically

18 evaluate both strengths and challenges associated with their use. 


\section{1. Introduction}

21 Forests provide critical ecosystem services to society, including provision of food

22 and fiber, maintaining water availability and quality, and regulating climate (Krieger,

23 2001; Millennium Ecosystem Assessment, 2005). Sustaining these services under

24 increasing societal demand depends on effective forest management, which in turn relies

25 on solid scientific understanding of the natural processes of carbon, water, and nutrient

26 cycling. Historically, much of our scientific knowledge on key ecological processes and

27 management impacts has come from field-based studies and experimental manipulations.

28 To extrapolate this understanding to larger domains in both time and space, however,

29 requires scaling techniques often based on forest inventories and ecological modeling.

30 Upscaling plot-level measurements of carbon, water and nutrient cycling in forests to

31 broader spatial and temporal scales can be accomplished by different approaches

32 including measure-and-multiply, or "book-keeping”, techniques (e.g., Houghton et al.,

33 1983), formal national-level resource inventories (e.g., Heath et al., 2011), and

34 mechanistic modeling of biogeochemical processes (e.g., Thornton et al., 2009). Across

35 these various scaling approaches are common data requirements for initializing,

36 calibrating, driving and validating these methods.

37 Remote sensing observations and derived products fill a critical role in meeting these

38 data requirements, particularly where spatially- and temporally- explicit information is

39 needed for inputs and evaluation (Turner et al., 2004). In theory, remote sensing is

40 straightforward. Energy from either the sun or the sensor itself can be interpreted as it 
41 interacts with the Earth's surface to infer forest attributes or, as observations are

42 combined over time, change. These inferences can be made over different spatial scales

43 and frequencies, with consistent records going back decades in some cases. From this

44 simple concept however come a large variety of sensors that vary by platform, passive or

45 active systems, spectral wavelengths, spatial resolution and coverage, and repeat

46 frequency and available historical record (Jensen, 2009). The choice of system, or

47 combination of systems, depends on the scale of the application or process of interest and

48 the particular forest attribute of interest (e.g., composition, structure, productivity, water

49 balance, or disturbance).

50 Here we review current remote sensing capabilities that can be used to characterize

51 carbon, water, and nutrient cycling in managed forests. Our particular focus is

52 describing remote sensing data and products describing key ecosystem attributes that can

53 be used to parameterize process-based models, or scale inventory and field measurements

54 to regional or even global extents. Despite the wide differences across the various

55 scaling approaches, there are common spatio-temporal data requirements that can be

56 addressed by remote sensing. Accordingly, we discuss the application of remote sensing

57 to four key ecological aspects of forests: composition, structure, productivity and

58 evapotranspiration, and disturbance dynamics.

59 Our emphasis is not exclusively on data sources that directly inform forest

60 management (which often requires spatial resolution at the scale of individual stands), but

61 more broadly on data sources useful for studying the ecological impact of forest

62 management as a land use practice. We also note that the definition of "managed forest"

63 itself is ambiguous, encompassing management goals as diverse as maximizing 
64 extraction (rapid rotation harvest, fertilization, thinning) and minimizing disturbance (fire

65 suppression, protection from development). For example, large swaths of forest in the

66 US and Canada are designated as "managed", although their composition and structure

67 do not differ substantially from "natural" forests with similar land use history. Most of

68 the discussion in this paper focuses on extractive management, including clear-cutting,

69 partial harvest, and planting, by which human activities rapidly alter forest attributes.

70 Given the increased societal attention to forest resource pressures and environmental

71 uncertainty, we also discuss emerging challenges and opportunities in the use of remote

72 sensing to inform forest science, management, and policy.

\section{Remote Sensing and Scaling Approaches}

75 To support sustainable management of forest resources, we need to understand the

76 broader implications of our local-scale knowledge of ecological processes. Most any

77 scaling approach will first require at least one - or more typically many - geospatial map

78 product(s) describing forest attributes across the landscape of interest. Whether using a

79 simple spreadsheet or "book-keeping" approach (e.g., Houghton et al, 2003) or more

80 sophisticated process-based simulation modeling (e.g., Melillo et al., 1993), the basic

81 premise of a scaling approach is to associate a particular parameter with the land cover or

82 forest type where it was measured, and then extrapolate its local value according to the

83 areal extent and spatial pattern of that type across the mapped landscape. For example, in

84 their book-keeping approach to estimate the forest-sector greenhouse gas budget of

85 Mexico, de Jong et al. (2010) developed a nation-wide initial biomass estimate by 
86 extrapolating measured, per area carbon stock density values to the spatial extent of the

87 main forest cover types based on medium spatial resolution $(30 \mathrm{~m})$ satellite data

88 classification. In U.S. forests, higher spatial resolution maps of composition and

89 structural attributes have been achieved using statistical scaling techniques that integrate

90 inventory plot data with optical- and laser- based remote sensing (e.g., Blackard et al.,

91 2008; Ohmann et al., 2014; Zald et al., 2014). At the global-scale, process-based

92 simulations by biogeochemical and land surface models require initialization with maps

93 of plant functional types (PFTs) that are typically based on coarse resolution $(\sim 1 \mathrm{~km})$

94 remote sensing data products (e.g., Jung et al., 2006; Huntzinger et al., 2013;

95 Wullschleger et al., 2014). Where data products are available at finer scales $(\sim 1 \mathrm{~m}-$

$9630 \mathrm{~m}$ ), some process-based modeling applications can be directly initialized with

97 spatially-explicit data on forest biomass (e.g., Kimball et al., 2000), structural

98 characterizations (e.g., Hurtt et al., 2004) or foliar chemistry (Ollinger and Smith, 2005)

99 (Fig. 1).

100 Repeat remote sensing imagery that captures forest dynamics through multiple

101 observations over time is also used to explicitly drive inventory and modeling approaches

102 for quantifying changes in carbon, water and nutrient cycling at landscape to regional

103 scales. While model initialization data incorporate the spatial variability of a particular

104 parameter, remote sensing driver data are used to represent the temporal dynamics of that

105 parameter. In the greenhouse gas accounting example cited above, de Jong et al. (2010)

106 calculated the change in Mexico forest-sector carbon stocks by updating their initial area-

107 based biomass estimate with two time-periods of spatially-explicit land cover change

108 maps classified from Landsat imagery. The national carbon accounting system in Canada 
109 is also largely driven by modeling the components of change based in part on remote

110 sensing of forest disturbances, such as wildfires and insect outbreaks (Kurz et al., 2009).

111 Similarly, these components of change can be incorporated into simulation modeling

112 frameworks to capture the impacts of disturbance and land use change on ecosystem

113 processes (e.g., Galford et al., 2010; Hayes et al., 2011; Turner et al., 2011). Remote

114 sensing indices are also used in empirical and explicitly diagnostic scaling approaches,

115 such as the global estimation of vegetation productivity based on the light-use efficiency

116 (LUE) approach (Running et al., 2004) and the upscaling of site-level observations of

117 carbon, water and energy fluxes based on eddy-covariance techniques (Jung et al., 2011).

118 There are also many examples of numerical modeling frameworks that directly

119 incorporate satellite-derived productivity indices as key drivers in diagnostic simulations

120 of ecosystem processes (e.g., Potter et al., 1993; Coops and Waring, 2001; Turner et al., 121 2006).

122 A final data requirement for ecosystem scaling approaches is a set of known target

123 values to both calibrate and validate the empirical or numerical simulation model. These

$124 \mathrm{cal} / \mathrm{val}$ data are often subsets of the same type and source, and historically have primarily

125 come from plot-based measurements. These site-level data can be used to parameterize

126 and verify ecosystem process models for particular forest types (e.g., Medvigy et al.,

127 2009; Richardson et al., 2010), but available data are limited in both space and time. To

128 capture broader spatio-temporal variability in model evaluation, studies of forest carbon,

129 water and energy exchange have made use of regional-scale networks of eddy-covariance

130 towers (Fisher et al., 2008; Schaefer et al., 2012). Still, the spatially and temporally

131 limited observations from these networks can underrepresent important forest regions and 
132 associated ecological processes (Hargrove et al., 2003; Hayes and Turner, 2012). Remote

133 sensing data have the potential to provide spatially and temporally explicit, consistent and

134 comprehensive benchmarks for model evaluation (Luo et al., 2012; Mao et al., 2012).

135 Remote sensing data can also be directly assimilated into process-based models as a

136 constraint on system dynamics (e.g., Luo et al. 2011, Quaife et al. 2008, Rayner et al.

137 2005).

138 The various scaling approaches each offer advantages and disadvantages depending

139 on the science or management question being addressed. Because each approach might

140 focus on a different aspect of carbon, water and nutrient cycling, the choice of approach

141 is important and any cross-evaluations must be careful to consider "apples-to-apples"

142 comparisons (Hayes and Turner, 2012). Although there are benefits in retaining

143 independence for such comparisons, progress can also be made in scaling questions by

144 considering multiple constraints (Hayes et al., 2012) as well as more formally integrating

145 across approaches (Turner et al., 2013). Remote sensing can serve as a key integrator in

146 this effort, where opportunities exist to use repeat coverage, spatially-explicit data to

147 calibrate, initialize, drive and validate both inventory and modeling approaches to scaling

148 forest ecosystem processes. Along with these opportunities, however, come significant

149 challenges with the use of remote sensing in managed forests. There are methodological

150 limitations and various sources of error in remote sensing data themselves that need to be

151 overcome. In most cases, it is not possible to remotely sense the ecological process of

152 interest directly, and thus to produce the desired output some level of model (which itself

153 needs calibration and validation) is required. At the foundational level, though, remote

154 sensing data and methods have demonstrated the ability to inform scaling studies of 
155 ecological processes by characterizing their underlying indicators. Here, we review the

156 state-of-the-art in remote sensing of these indicators in managed forests, namely

157 composition, structure, productivity and evapotranspiration, and disturbance dynamics,

158 and discuss the opportunities and challenges going forward for this important field of

159 research.

\section{Forest Composition}

162 To accurately represent ecological processes, models require some depiction of

163 vegetation composition. Typically, models parameterize rate constants (e.g. mortality,

164 carbon allocation, plant-atmosphere fluxes) by assigning values based on vegetation type

165 (e.g. Hudiberg et al., 2009). Historically, vegetation type was assigned at coarse

166 resolution using fixed land cover classes based on climate regimes or field observations

167 (Matthews, 1983). With the advent of reprocessed global AVHRR satellite data in the

168 mid-1980's, researchers began to construct global land cover representations at finer

169 scales, and with additional information derived from seasonal observations of vegetation

170 greenness (Tucker et al., 1985; Justice et al., 1985; Loveland et al., 2000). Remote

171 sensing classification schemes for land cover have typically relied on stratification among

172 a few key structural and functional variables, including leaf type (needle, broadleaf), leaf

173 longevity (deciduous, evergreen), stem structure (herbaceous vs woody), and stature

174 (shrub vs. treed). Biogeochemical and ecological models have been parameterized

175 using global land cover maps derived from AVHRR, MODIS, and SPOT-Vegetation

176 (Jung et al., 2006; see also references in Section 5), ranging in spatial resolution from 
$177500 \mathrm{~m}$ to $8 \mathrm{~km}$, although other models specify vegetation types internally in response to

178 local edaphic conditions, climate, and competitive dynamics (Quillet et al., 2010).

179 For global models operating at $1 / 4$ to 1 degree, a challenge has been to adequately

180 represent the heterogeneity of land cover classes within a single grid cell. In many cases

181 models simply adopt the most common, or modal, land cover type to represent the entire

182 cell. However this practice tends to underestimate the biophysical impacts of small,

183 disaggregated land cover types such as urban areas, small-scale agriculture, wetlands, and

184 riparian forests. More sophisticated parameterizations incorporate observed mixtures of

185 land cover within each cell, essentially running separate model simulations for each land

186 cover fraction, and then aggregating the component fluxes and stocks (Koster and Suarez,

187 1992; Bounoua et al., 2006; Melton and Arora, 2014) or tracking them as individual but

188 not spatially-explicit “cohorts" (Hayes et al., 2011).

189 Identifying managed forests as a specific class often requires combining information

190 on both composition and temporal dynamics. Large plantation monocultures, such as oil

191 palm and eucalyptus have been successfully mapped using MODIS time series data. In

192 the case of Eucalyptus, short-rotations (6-7 years) provide a diagnostic NDVI signature

193 (le Maire et al., 2014; Marsden et al., 2010). Oil palm has been mapped via diagnostic

194 phenology compared to surrounding forest (Guiterrez-Velez and Defries, 2013), as well

195 as visual interpretation of high-resolution data (Thenkabail et al., 2004) and application

196 of traditional classification approaches to radar and optical data (Santos and Messina,

197 2008). In other cases, identifying managed forests relies less on unique phenology or

198 spectral signatures, and more on the relative level of disturbance activity compared to

199 "natural forests". For example, the prevalence of stand-clearing disturbance in the 
200 southern United States is readily ascribed to pine forestry across much of the region

201 (Masek et al., 2008; Hansen et al., 2010). In regions with less intensive management

202 practices, including selective harvest and partial harvest, it may be difficult to separate

203 the temporal signature of management from natural disturbances such as storm damage

204 and insect mortality (Thomas et al., 2011).

205 The use of remote sensing derived land cover within ecological models is by now

206 well established, and recent attention within the remote sensing community has focused

207 on creating more ecologically relevant descriptions of composition. In particular, the

208 concept of mapping vegetation functional types, rather than land cover types, has gained

209 currency. While the precise definition of functional type has been debated (Gitay and

210 Noble, 1997), the term refers to plant communities that either share a common ecosystem

211 function, or share a common response to a perturbation such as disturbance or stress. In

212 theory a landscape unit can have multiple descriptions incorporating function, response to

213 stress, structure, and temporal behavior. Thus, rather than simply stratifying vegetation

214 into fixed classes, a given patch could (for example) fix nitrogen, feature serotinous

215 reproductive strategies, and be a woody perennial.

216 Derivation of functional types has commonly centered on the use of fine spectral

217 resolution (hyperspectral) data in order to discriminate among different plant attributes.

218 Physically, the use of hyperspectral data allows retrieval of specific biochemical

219 compounds associated with plant function and structure, including foliar nitrogen, $\mathrm{C} / \mathrm{N}$

220 ratios, chlorophyll concentration, and structural compounds (lignin, cellulose) (Kokaly et

221 al., 2009; Ustin et al., 2009). Numerous studies have used hyperspectral imagery to map

222 specific plant communities (Roberts et al., 1998; Clark et al. 2005) and functional traits 
223 (e.g. Asner and Vitousek, 2005; Asner et al., 2015). However, reliably translating leaf-

224 level reflectance spectra to the canopy scale remains challenging. While foliar chemistry

225 and structure control leaf-level spectra, canopy spectra are strongly affected by forest

226 structure (eg. leaf-area, branch area, shadowing), compositional mixing among multiple

227 species, and non-vegetated components such as soil visible through canopy gaps (Asner

228 et al., 2008). Thus care must be taken to consider the role of canopy structure as well as

229 leaf biochemistry in interpreting observed reflectance spectra (e.g. Knyazikhin et al.,

230 2013). In addition, there are currently no operational hyperspectral observatories in orbit

231 that provide routine global coverage. Limited data have been collected by the EO-1

232 Hyperion sensor since 2000, and new data are planned from the German EnMAP satellite 233 beginning in 2018.

\section{4. Forest Structure}

235 Forest structure refers to the three-dimensional organization of individual trees on

236 the landscape, as well as the way that canopy elements fill space. Specific structural

237 attributes derived from remote sensing include stand height, stem density, fractional

238 canopy cover, canopy vertical distribution, and biomass. Knowledge of forest structure is

239 critical for ecosystem modeling for several reasons. First, structural elements such as

240 height and stem density are directly related to above-ground biomass and thus carbon

241 storage (Hall et al., 2011). Ecosystem models can use observed biomass data to constrain

242 productivity and wood turnover so that, for example, potential biomass within the model

243 does not exceed maximum observed biomass (Williams et al., 2012; 2014). In addition,

244 models that explicitly include size or age cohorts benefit from knowing the distribution of 
245 tree sizes within a model grid cell. For example the Ecosystem Demography (ED) model

246 accounts for the growth and aging of individual trees, and can adjust aggregate

247 productivity based on observed height distributions (Hurtt et al., 2004; Thomas et al.,

248 2008; Antonarakis et al. 2011). Finally, at the scale of individual trees, the distribution of

249 leaf area and canopy gaps controls the radiation balance at various levels within the

250 canopy. In principle such information could be used to drive explicit models of

251 photosynthesis within the canopy, although to date most models do not approach that

252 level of detail (Loew et al., 2014).

253

\subsection{Remote Sensing of Structure}

255 A variety of remote sensing technologies have been used to retrieve vegetation

256 structural attributes (Fig. 1). Passive optical techniques rely on reflected solar radiance to

257 provide information. Active techniques probe vegetation canopies using energy emitted

258 from the remote sensing platform itself, and include radar and lidar approaches.

259 Passive optical methods have been used for over four decades to retrieve vegetation

260 structure and biomass, but have met with inconsistent results (Lu, 2006). Canopy

261 reflectance tends to be dominated in the visible and near-infrared by the outer layer of the

262 canopy foliage. In the visible wavelengths, too little light passes through the leaves to

263 probe deeper structural levels, while in the near-infrared multiple scattering among leaves

264 leads to an asymptotic saturation of the signal regardless of structure (Asner et al., 1998).

265 As a result, there is little information provided on vertical structure in closed canopy

266 forests. However, passive optical data are sensitive to the spatial arrangement of 
267 shadowing and "background" (e.g. soil, litter) exposure across the landscape. Passive

268 optical data are thus useful for determining canopy cover, and, in sparse forests where

269 cast shadows are diagnostic of tree heights, passive optical data have been used to

270 retrieve biomass with relatively high accuracy (Cohen and Spies, 1992; Hall et al., 2006).

271 In addition, for younger stands where both height and reflectance are changing rapidly,

272 time series analysis of reflectance trajectories have been successfully correlated with

273 current-year biomass (Pflugmacher et al., 2012).

274 Radar and lidar methods tend to perform better than passive optical methods in

275 higher biomass, closed canopy forests (Zolkos et al., 2013). Radar backscatter using

276 longer wavelengths (e.g. L-band, P-band) provides penetration of the canopy branch

277 structure, but tends to saturate at biomass levels higher than $\sim 100 \mathrm{Mgha}^{-1}$ AGB (Imhoff

278 1995). More recent studies have used radar interferometry (based on converting the

279 phase shift between spatially separated radar signals to calculate distance to the receiver)

280 to characterize the surface and the interior "topography" of canopies (Treuhaft et al.,

281 2004). Interferometric techniques have been shown to be sensitive to biomass up to 300-

$282400 \mathrm{Mgha}^{-1}$ AGB for X- and P-band (Treuhaft et al., 2015; Minh et al., 2014). Current or

283 upcoming radar missions include the Japanese PALSAR-2 (L-band), the European

284 Sentinel-1 mission (C-band), the European BIOMASS mission (P-band, to be launched in

285 2020), and the US/Indian NISAR (S- and L-band, to be launched in 2020).

286 Lidar is often considered to be the optimal remote sensing approach for retrieving

287 structural attributes in higher biomass forests where other methods saturate, since it

288 provides a direct measure of both the vertical and spatial distribution of canopy elements.

289 In particular, lidar can directly measure stand height, which correlates strongly with 
290 biomass (Hall et al., 2011). Discrete return lidar systems collect the timing of the first

291 (or first and last) reflected pulse (Lim et al., 2003). Airborne discrete returns often

292 provide very dense sampling, with detection of up to 20 returns per square meter,

293 generating point clouds that visually depict individual tree crowns, terrain, and

294 understory (Fig 2). As noted below, such information can be used to parameterize

295 individual-based ecosystem models (Hurtt et al., 2004; Thomas et al., 2008; Antonarakis

296 et al. 2011). Waveform lidar systems collect the full distribution of reflected energy from

297 the canopy, essentially providing a vertical profile of the canopy density (Lim et al.,

298 2003). Various studies have reported success in retrieving biomass levels of up to 300-

$299400 \mathrm{Mgha}^{-1}$ using full-return lidar, although site characteristics (including species

300 composition and local topography) may reduce retrieval accuracy (Ahmed et al., 2013).

301 4.2. Applications

302 With the increase in satellite-based radar and lidar systems (e.g. ICESat GLAS,

303 ALOS PALSAR), a number of recent studies have used remote sensing observations in

304 conjunction with field data to create map-based estimates of above-ground biomass for

305 the pan-tropics (Saatchi et al., 2011; Bacchini et al., 2011), the United States

306 (Kellendorfer et al., 2004); and the circum-Arctic (Neigh et al, 2013). These efforts have

307 typically used multiple remote sensing inputs, and statistical modeling techniques to

308 "train" regression models based on available field data, and provide map estimates with

309 spatial resolution of $30 \mathrm{~m}$ to $1 \mathrm{~km}$. The high uncertainty associated with these products

310 (often 20-40\%) reflects limitations in the amount of field-measured biomass available

311 across the globe, as well as limitations in current radar and lidar datasets. For example,

312 although ICESat GLAS has been used in many recent studies, its spatial resolution ( $\sim 60-$ 
31380 meters) is not optimal for measuring vegetation structure in complex terrain. When

314 implemented on the International Space Station (ISS) in 2018, the NASA Global

315 Ecosystem Dynamics Investigation (GEDI) vegetation lidar should improve the quality of

316 biomass datasets by providing denser laser sampling, as well as finer spatial resolution

317 (20 meters) for each laser spot. Due to the ISS orbit, only land areas between 52 degrees

318 north and south will be mapped during the GEDI mission.

319 One complication, however, is that traditional modes of inference do not easily

320 support uncertainty analysis of forest population parameters derived by simply adding up

321 modeled pixel values. This is evident, for example, when the ecoregion-level biomass

322 values implied by alternative maps do not intersect each other's confidence intervals

323 (Mitchard et al., 2014). There are, however, straightforward ways to integrate lidar

324 measurements as discrete observations in a formal sample/survey framework (Wulder et

325 al., 2012), an approach which has been pursued using both airborne (Ståhl et al., 2010)

326 and spaceborne (Healey et al., 2012) lidar data. GEDI will likely incorporate these

327 principles in order to improve population estimates. The improved sampling density of

328 GEDI should allow biomass estimates with $<20 \%$ absolute error within cells finer than

32925 ha, a scale approaching that at which individual forest tracts may be managed.

330 A number of studies have successfully used active remote sensing to retrieve

331 structural attributes in managed and disturbed forests, and to distinguish structural

332 differences associated with forest extraction. Dolan et al (2011) found a significant

333 change in regional stand height before and after Hurricane Katrina using ICESat GLAS

334 data. Similarly, Margono et al (2012) found a statistically significant difference in

335 GLAS-derived canopy height between primary intact and primary degraded forests in 
336 Indonesia. Ryan et al (2012) used three-years of L-band radar from ALOS PALSAR to

337 identify changes in carbon stocks in degraded Mozambique woodland as small as 12

$338 \mathrm{Mgha}^{-1}$ with $95 \%$ confidence. These results indicate the potential of active remote

339 sensing to quantify specific levels of forest extraction or degradation apart from simply

340 stand clearing events such as clearcutting. An innovative study by d'Oliveira et al (2012)

341 used airborne lidar to identify subcanopy logging roads and skid trails in a degraded

342 section of Amazonian forest (Brazil). A key finding was the ability of lidar to map

343 specific management practices that would otherwise be hidden by the overstory canopy.

344 In addition to characterizing the current state of forests, active remote sensing can be

345 used to monitor long-term changes in structure. The most direct approach is to use the

346 same instrumentation to acquire repeated lidar or radar datasets over a period of years.

347 Particularly in the case of lidar, there have been relatively few experiments of this nature

348 to date. Dubayah et al (2010) used repeated measurements from the LVIS airborne lidar

349 system over La Selva, Costa Rica to map height and biomass change between 1998 and

3502005 . In addition to recording losses due to clearing and disturbance, they were able to

351 identify areas of increasing height and biomass within growing, secondary forests.

352 Similarly, Rosette et al. (2015) used repeated measurements from LVIS (2009-2013) to

353 identify structural changes associated with forest management in Howland, Maine.

354 Since comparable, repeat-pass lidar datasets remain rare, a number of studies have

355 combined one-time structure information from lidar with disturbance history from

356 passive optical sensors such as Landsat or MODIS. For secondary forests, knowing the

357 time since clearing (from historic Landsat imagery) and current biomass from lidar, the 
358 mean rate of biomass accumulation across a region may be obtained (Helmer et al., 2009;

359 Dolan et al., 2009).

\section{Forest Dynamics and Disturbance}

361 Disturbance processes that result in tree growth decline and/or mortality are a

362 ubiquitous and constant feature of managed forest landscapes (Fig. 3). Disturbances can

363 be caused by natural processes such as wildfires, insects and disease, and wind-throw and

364 storm events, or from anthropogenic processes such as logging, pollution, deforestation,

365 and the introduction of invasive species. The broader landscape patterns of forest

366 composition, structure and function are a reflection of the regional disturbance regime,

367 defined by the dominant type, extent and frequency of disturbance. Superimposed on

368 climate and landscape characteristics, disturbance is a key determinant of forest

369 heterogeneity at regional scales (Sousa, 1984).

370 Disturbance events change the composition and structure of the forest, alter carbon,

371 water and nutrient cycling, and reset successional processes (Goward 2008, Williams

372 2014, Hicke 2012, Chambers et al. 2007). The impacts of disturbance on forests are both

373 direct, as with short-term tree mortality and the mass transfer of carbon, and indirect

374 through modifying the physical environment that influences longer-term successional

375 trajectories of carbon, water and nutrient cycling (Kasischke et al. 2013). At the local-

376 scale, the amount and nature of mortality, carbon transfers and physical impacts are all

377 dependent on the type and severity of disturbance (Keeley 2009; Goetz et al. 2012). The

378 broader-scale impacts over time and space depend on the frequency and extent of

379 disturbances over larger areas. Characterization and quantification of these key attributes 
380 of forest disturbances (i.e., type, severity, frequency and extent) are required for

381 estimating or simulating the ecological impacts of forest disturbances in scaling

382 frameworks and process models (Liu et al. 2011).

383 Here we review and discuss the opportunities and challenges in employing different

384 remote sensing technologies and methods for creating the disturbance data products

385 needed for informing process scaling studies in managed forest ecosystems. Although

386 there are many different definitions of disturbance (Sousa 1984, Scheffer 2002, Godron

387 Forman 1983, Pickett and White 1985, Bender 1984), we define forest disturbance here

388 as those processes, both anthropogenic and natural, that result in a loss of forest biomass

389 and redistribution of carbon within the ecosystem. Conversely, those processes that result

390 in post-disturbance changes in vegetation growth we refer to as "regeneration", which

391 should be contrasted with "recovery" in that it does not imply a return to the initial state.

\subsection{Characteristics of disturbance}

393 Individual disturbance events can be described by parameters representing cause (or

394 "agent"), spatial extent, severity, duration, and selectivity. In general, the range of

395 disturbance types can be categorized according to more localized and immediate pulse

396 disturbances causing abrupt change versus press disturbances that result in more gradual

397 impacts over broader areas and longer periods of time (Fig. 3). The choice (and

398 effectiveness) of particular remote sensing data and techniques to detect and characterize

399 different disturbance types varies with these press-pulse characteristics.

400 Disturbance events with small spatial extents, relative to the spatial grain of 401 remotely-sensed imagery, are substantially more difficult to reliably discriminate from 
402 noise than larger events. For example, when using satellite imagery with a $30 \mathrm{~m}$

403 resolution, detection of a large harvest unit is a straightforward detection task whereas

404 identifying tree-fall gaps would require higher resolution imagery with a spatial grain of a

405 few meters. Stand clearing events such as clear-cuts, land-use conversion, and severe

406 fires generate strong signals that can easily be detected through optical remote sensing,

407 whereas subtle changes from nutrient deposition, drought stress, or thinning can be

408 difficult to differentiate from phenological differences or errors in surface-reflectance

409 corrections, particularly if they are over large areas on the order of kilometers and have

410 with indistinct borders.

411 In addition to varying in size and severity, events can vary in the species-selectivity

412 of the agent (Frolking 2009). The hemlock wooly adelgid, for example, is a species-

413 specific invasive insect that attacks and kills only Eastern hemlocks (Orwig 2012),

414 whereas the Asian gypsy moth is a generalist parasitoid that affects many deciduous

415 species (Townsend 2012). Additionally, wildfires can affect a range of individuals with

416 varying impacts depending on species and size (Garren 1943). Species-selective

417 harvesting, as opposed to simply choosing mature trees or clear-cutting, can have similar

418 effects. Though species-selective disturbances always have the same detection challenges

419 as low-severity disturbance, they introduce the additional issue of tracking a shifting

420 spectral signal as forest species-composition shifts. Similarly, other disturbances which

421 leave a mostly intact overstory canopy, such as understory fires or harvest, controlled

422 burns, and construction of narrow roadways $(<\sim 6 \mathrm{~m})$, pose detection problems for

423 spectral sensors (Peres et al 2006).; lidar-derived structural information is useful for

424 identifying these types of events (Azizi 2014). 
425 Finally, both pulse and press disturbance events require appropriate techniques for

426 detection. Pulse disturbances may go undetected if the spectral signal returns to pre-

427 disturbance values within span of the detection technique's temporal window though

428 Townsend's (2012) method for quantifying Gypsy Moth defoliation in the Eastern United

429 states was broadly successful, with a single fixed-effects model producing a mean

430 absolute error of $10.8 \%$ defoliation from a cross-validated sample. Conversely, remote

431 sensing methods to detect press events, such as from progressive insect and disease

432 outbreaks, remains challenging since many algorithms are based around the concept of

433 detecting discrete events, rather than long-term decline (Holmgren, 1998; Goodwin,

434 2008; Frolking, 2009; Oumar, 2011).

$435 \quad$ 5.2. Remote sensing methods for Disturbance

436 Remote sensing methods to characterize forest disturbance typically rely on first

437 deriving a spectral signature of vegetation through which changes can be detected. A

438 commonly used signature, the normalized difference vegetation index (NDVI,

439 Tucker1979), subtracts the red reflectance from near-infrared reflectance to exploit the

440 'red cliff' in the chlorophyl absorption spectra and thereby estimate chlorophyl

441 concentration. Other common signatures include the normalized burn ratio (NBR,van

442 Wagtendonk 2004), which is used to detect wildfire disturbance (Eidenshink 2007), and

443 the normalized difference moisture index (NDMI), which has been shown to better

444 correlate with biomass by also capturing information about forest canopy shadowing and

445 structure (Wilson and Sader, 2002). 
446 The satellite imagery products most suitable for monitoring managed forest

447 disturbances are constrained by those that are continually acquired, rather than tasked,

448 and are openly available to the public at low- (or no) cost. As such, for forest monitoring

449 purposes, the most common datasets used are those generated from the MODIS sensors

450 onboard the Aqua and Terra satellites (Justice et al., 2002) and the sensors aboard the

451 Landsat family of satellites (Vogelmann et al., 2009). MODIS imagery is available since

452 2000, and new views are acquired every one to two days. NDVI products can be

453 generated at $250 \mathrm{~m}$ resolution from MODIS imagery, though other spectral bands are

454 sampled at coarser resolution. Though the large spatial grain can subsume smaller

455 managed forest plots, the high temporal resolution facilitates continuous monitoring,

456 thereby alerting managers of potential problems that can be spatially pinpointed by other

457 means. Landsat Thematic Mapper data at $30 \mathrm{~m}$ resolution are available since 1982, with

458 an opportunity for new acquisitions every 16 days for each satellite; though, due to data

459 constraints, a new image is not acquired at every opportunity. Additionally, the

460 Multispectral Scanner (MSS) instrument aboard early Landsat satellites can extend views

461 back to 1972, though at a resampled spatial resolution of $60 \mathrm{~m}$, a 4-band spectral

462 resolution, and an 18-day return time for Landsat 1 through 3. Despite its potential,

463 though, only a few disturbance detection applications have utilized this legacy Landsat

464 data (e.g. Healey et al., 2008) because its use in time series analysis currently requires

465 significant additional radiometric and geometric processing beyond standard archived

466 formats. In the future, the European Global Monitoring for Environment and Security

467 (GMES) Sentinel-2 mission promises to provide free and open 10 to $60 \mathrm{~m}$ resolution

468 imagery every imagery every -five days at the equator by using two satellites, with orbit 
469 characteristics that complement connecting data with observations from SPOT and

470 Landsat (Drusch et al., 2012), thereby gaining some of the temporal advantages of

471 MODIS at much higher spatial resolution.

472 Early methods to detect forest disturbance from remotely sensed imagery would

473 typically compare two images representing vegetation acquired on two different dates

474 with the difference between the images expressing change (Hayes and Sader, et al., 2001;

475 Garcia-Haro, 2001; Masek et al., 2008). Most often, these would be acquired before and

476 after known disturbance events to assess the extent and magnitude of the event of interest

477 (Chambers et al. 2007, White et al. 1996, Wimberly and Reilly, 2007). Like other

478 methods, the magnitude of the spectral change correlates with the disturbance severity.

479 To a large extent two- or three-date comparisons to find forest disturbance were

480 necessitated by the expense of individual Landsat scenes. With open access to the

481 archive since 2008, methods that incorporate much more data have become popular

482 (Vogelmann 2009) (Fig. 4). These methods can provide both the location and times of

483 disturbance events to create historical baselines of disturbed areas or for ongoing

484 monitoring. The Vegetation Change Tracker (VCT) finds disturbances by detecting

485 deviations in the vegetation index time-series and labeling these years as disturbed

486 (Huang et al. 2010). LandTrendr (Kennedy et al. 2007) finds disturbances by fitting a

487 piecewise linear trend to the vegetation index time-series and then labels segments with

488 negative slope as disturbances. Both of these methods use Landsat imagery and generate

489 a single clear-sky composite image for each year which is then used to detect change. To

490 increase temporal resolution, the methods of Zhu \& Woodcock (2012), utilize all

491 available Landsat data to model and remove phenology. 
To increase temporal resolution even further, one approach is to combine daily

493 observations from MODIS with higher-resolution observations from Landsat (e.g. Hilker

494 et al., 2009). The opening of the archive has also facilitated studies with very large

495 spatial extents, such as the mapping of the entire globe from 2000 to 2012 using Landsat

496 data and the Google Earth Engine performed by Hansen et al (2013). Using only MODIS

497 data, the ForWarn system groups phenological patterns into a set of clusters and then uses

498 deviations from the expected pattern to detect forest change in with delays measured in

499 weeks or days. These techniques have shown promise in both the western United States

500 and in more species-rich Eastern United States forests (Hargrove et al. 2009).

\section{$501 \quad$ 5.3. Attributing Disturbance Events}

502 While attribution of disturbance type is critical for inclusion of remotely sensed

503 change data in models of carbon dynamics (Zhang 2012) and current and future climate

504 change impacts (Ayres 2000, Dale 2001), most disturbance maps do not specify type. A

505 major hurdle to creating effective and reliable attribution algorithms is the availability of

506 high-quality training data that labels known individual disturbances with a causal agent.

507 In most studies, the researchers themselves generate these data.

508 Work by Schroeder et al. (2011) in the Canadian boreal forest used Landsat imagery

509 to distinguish between forest fires and clearcuts that were manually identified by

510 analysts. Although limited to a relatively small spatial area, agent separation rates of $93 \%$

511 were achieved. The shortwave infrared bands contained the most reliable information and

512 imagery acquired soon after the disturbance event was the most effective, though

513 separation could still be achieved with imagery acquired up to four years after the event. 
514 Working over the entire Canadian boreal forest, Guindon et al. (2014) used MODIS

515 imagery to separate disturbances caused by fires, harvest, and floods. Using a decision

516 tree model, separation accuracies between $80 \%$ and $85 \%$ over the entire area were

517 achieved. Smaller and less-serve disturbances, though, were frequently omitted (up to

$51850 \%$ ), and the presence of other disturbance agents, such as insect outbreaks, emphasizes

519 the complexity of the attribution problem. Baumann et al. (2014) explored the separation

520 of anthropogenic harvest and natural windfalls using a support vector machine

521 classification approach over spectral information in Russian temperate forests and boreal

522 forests of the United States. The approach generated high classification reliability when a

523 disturbance was detected, but omitted many disturbance events less than approximately 5

524 ha in area. These approaches based on generating individual training data sets can be

525 inefficient as similar work is repeated and the comparability of methods is limited since

526 the set of disturbances detected and labeled differs between studies. The human

527 interpretation aspect of this approach can create bias since the same researchers generate

528 both the training data and the detection/classification tool.

529 Using information from the remote sensing imagery other than just pixel-by-pixel 530 spectral values may increase classification accuracy. Using a neural network approach

531 over spectral information and information about spatial variability and using known

532 disturbance extents from the US Forest Service's Aerial Detection Survey (McConnel

533 2000), eight difference disturbances were separated in temperate forests in the eastern

534 United States, including insect pests and diseases. Classification accuracies ranged from

$53542 \%$ to $90 \%$ for different agents, with reliabilities following a similar range and

536 performance matching the quantity of high-quality data available for training the 
537 classifier (Hughes 2014). Visual examination of forest disturbance events can often

538 reveal if the cause is harvest or some natural disturbance by the regularity of the

539 disturbance event. This follows the more general observation that more regular

540 landscapes are more heavily human-impacted (O'Neil et at. 1988). Classification using

541 the shape and regularity of disturbance patches is a promising approach to differentiating

542 between anthropogenic and natural disturbances (Antonova et al. 2013).

\section{Forest Productivity and Evapotranspiration}

$545 \quad$ Forest net primary production is an ecosystem service in the context of both

546 providing wood and driving carbon sequestration. Net primary production (NPP) is the

547 rate of carbon uptake by vegetation, which is the balance between photosynthesis, or

548 gross primary production, and autotrophic respiration (Chapin et al., 2006). Carbon

549 sequestration considers stocks and fluxes in additional ecosystem components (e.g., soils,

550 wood products, aquatic systems, and disturbances) and is determined as the longer-term

551 net ecosystem exchange (NEE) or net ecosystem carbon balance (NECB). Remote

552 sensing has been applied to scaling forest productivity and carbon budget estimation for

553 monitoring purposes using a range of approaches. Wood production can be mapped most

554 simply with statistical techniques that combine remote sensing data (e.g. Landsat), and

555 other spatially distributed datasets such as climate reanalysis, with forest inventory

556 measurements (Ohmann and Gregory 2002, Ohmann et al. 2012). For more process-

557 based approaches, a numerical model with algorithms for simulating some level of 
558 mechanistic detail in factors controlling vegetation and/or ecosystem production is

559 employed.

560

561 Table 1. Examples of different formulations of process-based models and how

562 remote sensing data is used in simulating forest and ecosystem productivity. The

563 examples shown here are taken from models participating in North American Carbon

564 Program synthesis and inter-comparison activities (Huntzinger et al. 2012, 2013).

565 Photosynthetic formulation is categorized by either enzyme kinetic (EK) or light use

566 efficiency (LUE).

\begin{tabular}{|c|c|c|c|c|c|c|c|}
\hline Model & $\begin{array}{l}\text { Photosynth. } \\
\text { Formulation }\end{array}$ & $\begin{array}{l}\text { Vegetation } \\
\text { Distribution }\end{array}$ & Phenology & $\begin{array}{l}\text { Leaf Area } \\
\text { Index }\end{array}$ & Fire & $\begin{array}{c}\text { Land Use } \\
\text { Change }\end{array}$ & Reference \\
\hline $\begin{array}{c}\text { CASA } \\
\text { GFEDv2 }\end{array}$ & LUE & MODIS & $\begin{array}{c}\text { GIMMS } \\
\text { NDVI }\end{array}$ & $\begin{array}{l}\text { Assimilated } \\
\text { from remote } \\
\text { sensing }\end{array}$ & $\begin{array}{l}\text { Prescribed } \\
\text { (MODIS) }\end{array}$ & None & $\begin{array}{l}\text { van der } \\
\text { Werf } \\
(2004)\end{array}$ \\
\hline CLM4 & EK & MODIS & Prognostic & $\begin{array}{c}\text { Dynamically } \\
\text { calculated }\end{array}$ & Prognostic & Modeled & $\begin{array}{c}\text { Thornton } \\
\text { et al. } \\
\text { (2009) }\end{array}$ \\
\hline ISAM & LUE & AVHRR & N/A & $\begin{array}{l}\text { Assimilated } \\
\text { from remote } \\
\text { sensing }\end{array}$ & Implicit & Modeled & $\begin{array}{l}\text { Jain and } \\
\text { Yang } \\
(2005)\end{array}$ \\
\hline TEM6 & EK & AVHRR & Prognostic & $\begin{array}{c}\text { Dynamically } \\
\text { calculated }\end{array}$ & $\begin{array}{l}\text { Prescribed } \\
\text { (various } \\
\text { RS } \\
\text { products) }\end{array}$ & Modeled & $\begin{array}{l}\text { Hayes et } \\
\text { al. (2011) }\end{array}$ \\
\hline VEGAS2 & LUE & Dynamic & Prognostic & $\begin{array}{c}\text { Dynamically } \\
\text { calculated }\end{array}$ & Prognostic & Modeled & $\begin{array}{l}\text { Zeng et } \\
\text { al. (2005) }\end{array}$ \\
\hline
\end{tabular}


568 Process-based simulation models come in several varieties (Table 1) that differ

569 significantly in organizing structure (Huntzinger et al. 2013, Fisher et al. 2014), which

570 determines their data input requirements. With respect to simulating NPP, process

571 models are broadly categorized into diagnostic -formulations, in which some variant of

572 leaf area index is prescribed by remote sensing, and prognostic formulations, which

573 simulate their own leaf biomass dynamics (Huntzinger et al. 2012). This categorization is

574 also a fundamental determinant for whether and how remote sensing data are used in the

575 modeling framework. Diagnostic models typically calculate photosynthesis based on a

576 light use efficiency (LUE) approach (Landsberg and Waring, 1997), which is driven

577 directly by remotely sensed measurement of absorbed photosynthetically active radiation

578 (APAR). Prognostic models, on the other hand, simulate primary productivity internally

579 via biochemical algorithms representing carbon assimilation or more detailed enzyme

580 kinetics (Farquhar et al. 1980).

581 A key observation underlying the light use efficiency scaling algorithm is that NPP

$582\left(\mathrm{gC} \mathrm{m}^{-2} \mathrm{yr}^{-1}\right)$ is generally correlated with APAR $\left(\mathrm{MJ} \mathrm{m}^{-2}\right)$. Hence, LUE can be

583 determined in terms of $\mathrm{gC} \mathrm{MJ}^{-1}$ and NPP estimated from APAR. It is gross primary

584 production (GPP), as estimated from measurements of net ecosystem exchange at an

585 eddy covariance flux tower (Waring et al. 1995), which is most closely related to APAR,

586 so LUE is often expressed in terms of GPP at a daily time step. Autotrophic respiration

587 (subtracted from GPP to get NPP) is commonly evaluated as a vegetation type specific

588 proportion of GPP (e.g. King et al. 2011).

589 Remote sensing contributes to the determination of APAR by providing an estimate

590 of the fraction of PAR (FPAR) that is absorbed by the vegetation canopy (Gower et al. 
591 1999). Empirical relationships of measured FPAR (or leaf area index) and spectral

592 vegetation indices, as well as radiation transfer theory, have been used to map spatial and 593 temporal patterns in FPAR (Myneni et al. 2002). Global and regional fields for daily 594 solar radiation and meteorological variables are now available from reanalysis data (e.g. 595 Zhang et al. 2007).

596 The simplest elaboration of the LUE scaling approach is to determine a maximum 597 LUE from flux tower observations and reduce it for stress factors related to 598 environmental drivers such as minimum air temperature and vapor pressure deficit. This 599 LUE approach has been applied globally using both AVHRR (Nemani et al. 2003) and 600 MODIS (Zhao and Running 2010) imagery. Validation studies at networks of eddy 601 covariance flux tower sites have helped evaluate and improve the MODIS-based 602 GPP/NPP algorithm (Turner et al. 2006, Heinsch et al. 2006). Applications have 603 included attempts to estimate the proportion of global primary production that is 604 appropriated for human use (Milesi et al. 2005).

605 Besides FPAR, remote sensing can potentially provide additional information 606 relevant to the LUE scaling approach. Several spectral vegetation indices have been 607 correlated with LUE in forest ecosystems (e.g. Nakaji et al. 2008). In addition, leaf-scale 608 (and to a lesser degree canopy-scale) observations suggest subtle shifts in the proportions 609 of different photosynthesis-related pigments that are detectable by way of changes in 610 reflectance of specific wave bands (Garbulsky et al. 2011). These features are best 611 observed with a high spectral resolution spectroradiometer such as AVRIS, but are also 612 potentially captured with MODIS wave bands (Goerner et al. 2011). Alternatively, there 613 is a signal associated with photosynthesis-driven chlorophyll fluorescence (Parazoo et al. 
614 2014) which is retrievable from space-borne sensors such as GOSAT and OCO-2. The

615 application of these advanced approaches has just begun and their operational use will

616 require a large calibration and validation effort (Grace et al. 2007).

617 While NPP simulation by prognostic models is not driven directly by remote sensing

618 data, both categories of models make use of derived products from remote sensing (e.g.,

619 plant functional type maps) for initialization, parameterization, extrapolation and

620 evaluation of productivity and carbon cycle indicator estimates (e.g., Huntzinger et al.

621 2013). In some cases, prognostic models 'predict' spectral indices such as the normalized

622 difference vegetation index that can be directly compared with satellite data (Mao et al.

623 2012). Prognostic productivity models that employ an enzyme kinetics photosynthesis

624 algorithm also commonly simulate a full carbon balance (e.g. Thornton et al. 2002).

625 Notably, heterotrophic respiration (which returns carbon to the atmosphere) must be

626 accounted for in tracking carbon sequestration using a flux simulation approach. Other

627 important fluxes potentially informed by the combination of remote sensing data and

628 process models include thinning/harvesting removals (Turner et al. 2011) and wildfire

629 emissions (Meigs et al. 2011). Potentially, all the information that is beginning to emerge

630 (from multi-temporal Landsat data, for example) on disturbance timing, attribution, and

631 magnitude can be input to an appropriately designed process model to simulate carbon

632 cycle impacts (e.g. Thornton et al. 2002).

633 The combination of ground-based observations, remote sensing, process models, and

634 top-down constraints, such as atmospheric $\mathrm{CO}_{2}$ fields derived from the OCO-2 sensor,

635 will provide an increasing clear picture of how forests are contributing to biosphere

636 metabolism (Running et al. 1999, Schimel et al. 2015). The capacity to monitor global 
637 forest carbon flux will thus be an important component in understanding the degree to

638 which forests act as a positive or negative feedback to the rising $\mathrm{CO}_{2}$ concentration (Pan

639 et al., 2011).

640 Evapotranspiration (ET) is the combination of evaporation of liquid water from land

641 surfaces, transpiration of water through plants, and the sublimation of ice or snow. The

642 energy required to evaporate water is the largest single heat source for the atmosphere,

643 and ET is therefore a critical link between the planet's energy and water cycles

644 (Vinukollu et al. 2011), and an important component of global hydrologic models.

645 Significantly for monitoring of forests (and vegetated systems in general), ET is central to

646 several drought stress indices (Anderson et al. 2010; Palmer 1965). Resulting drought

647 monitoring is useful in highlighting risk of fire and other forest health problems (X?).

648 Process-based Land Surface Models (LSMs) can be used to solve for ET (Chen et al.

649 1996), and remote sensing can provide important inputs to these models (Mu et al. 2011;

650 Vinukollu et al. 2011). For example, Marshall et al. (2013) estimated ET from a time

651 series of vegetation indices. Alternatively, an energy balance approach can be used with

652 thermal imagery to infer ET. The Landsat thermal band, present since the launch of

653 Landsat, has been used to estimate ET as a function of the difference between the

654 observed surface temperature and the heat energy in the atmosphere (Allen et al. 2007;

$655 \mathrm{Su}$ 2002). This band, present since Landsat 3 in the late 1970s, has a ground resolution of

656 approximately $100 \mathrm{~m}$ (varying to some degree across individual sensors). This spatial

657 resolution is useful for resolving ET trends at scales that are relevant for management

658 (Anderson et al. 2012), but Landsat's infrequent return interval, coupled with the fact that

659 clear-sky observations are required, places limits the applications for which Landsat is 
660 appropriate. Thermal data from the Geostationary Operational Environmental Satellites

661 (GOES), also available since the 1970s, provides a lower-resolution alternative that is

662 available much more continuously (Anderson et al. 2010).

663

664 7. Future Directions

665 Given the progress over the first four decades of remote sensing applications, it is of

666 interest to consider current developments that will lead to enhanced capabilities in the

667 future. The multispectral data sets at moderate (e.g. Landsat) and coarse (e.g. MODIS)

668 resolution represent the backbone for assessing the dynamics and composition of

669 managed forests. One emerging trend is the "MODIS-izing" of moderate resolution

670 observations, that is, the ability to construct near-daily time series observations at $<50 \mathrm{~m}$

671 resolution using multiple Landsat-type systems (e.g. Zhu et al., 2012). Data are now

672 acquired by an international constellation of moderate-resolution systems including

673 Resourcesat, CBERS, Sentinel-2, and Landsat. Harmonizing and merging just the

674 Sentinel-2 and Landsat observations will provide $\sim 2-3$ day coverage of the entire globe

675 by mid-2016. While data availability remains a thorny issue, the technical means to

676 provide daily, $<50 \mathrm{~m}$ multispectral data exists today. A benefit of such a record would be

677 the ability to derive biophysical variables (including vegetation phenology) at the scale of

678 individual forest management units, as well as the ability to characterize short-term

679 disturbances such as defoliation events or thinning.

680 New approaches for characterizing photosynthesis, productivity, and stress from

681 remote sensing are gaining currency. As noted above, solar-induced fluorescence has 
682 been linked to photosynthetic uptake and light-use efficiency in laboratory measurements 683 (Bilger et al., 1995; van der Tol et al., 2014), and more recently has been retrieved from 684 satellite data (Joiner et al., 2011). The Photochemical Reflectance Index (PRI) has been 685 shown to be indicative of vegetation stress (Drolet et al., 2005), and multi-angle 686 approaches to retrieval appear promising (Hilker et al., 2011). Taken together, these 687 findings suggest that we are on the cusp of being able to measure the canopy 688 photosynthetic energy budget via remote sensing. While this capability would be useful 689 for understanding primary productivity of forests, the real payoff might well be in 690 understanding how climate variability limits productivity through stress. For example, 691 tracking the response of $\mathrm{SiF}$ and PRI to evolving drought conditions may prove 692 informative as we consider the vulnerability of managed forests to future climate 693 conditions.

694 Structural measures from space are likely to evolve over the next decades as well.

695 The trio of upcoming lidar and radar missions (NASA GEDI, NASA/ISRO NISAR, and 696 ESA BIOMASS) should dramatically improve our knowledge of global biomass and 697 forest structure during the $\sim 2020$ era. A key opportunity, however, will be the extension 698 of this one-time coverage to periodic inventories, at a resolution sufficient to derive 699 stand-scale changes. Such a program would allow direct estimates of forest growth and 700 losses for individual parcels globally. To date, however, no country has an operational 701 program to conduct repeated surveys of forest structure from space.

702 More broadly, advances in information technology and miniturization of detector 703 hardware are leading to connected "sensor webs" that span in-situ, airborne, and satellite 704 platforms. Networked phenocams (Richardson et al., 2007; Sonnentag et al., 2012), low- 
705 cost terrestrial lidar, and UAV-based hyper spectral and lidar systems (Watts et al., 2012)

706 are starting to blur the lines between "field observation" and "remote sensing". As small,

707 inexpensive UAV and autonomous in-situ sensors become ubiquitous, forest remote

708 sensing will encompass continuous observations throughout the canopy.

$710 \quad$ 8. Conclusion

711 In this paper we have reviewed some of the many opportunities provided by remote

712 sensing to scale key forest ecosystem parameters over time and space, specifically those

713 related to composition, structure, productivity, and disturbance. Forest management

714 alters all of these parameters individually or (more commonly) in concert. The

715 availability of diverse remote sensing modalities including multispectral, hyperspectral,

716 radar, and lidar has steadily increased, and has led to improved ability to quantify

717 multiple forest attributes, and understand how they are affected by management regimes.

718 Some technologies (e.g. photosynthetic productivity estimated via solar-induced

719 fluorescence) are only now emerging and may prove to be powerful tools in coming 720 years.

721 As described in Section 2, the scaling of forest attributes may rely on interpolating

722 inventory or plot data, process-based modeling, or novel combinations of each approach.

723 Remote sensing has relevance to each approach and is often relied upon to produce

724 landscape-to-global estimates of key forest ecosystem parameters. Plot measurements

725 remain the "gold standard" for measurement accuracy, and when deployed as a 
726 systematic sample (e.g. in a well-designed forest inventory) such data provide unbiased

727 area estimates with known sampling uncertainties. They do not, however, provide

728 geospatial representation at the scale of forest management (ie. the scale of individual

729 stands). A challenge is to combine the measurement accuracy of plot and inventory data

730 with the spatial breadth of remote sensing. A variety of approaches have been proposed

731 to harmonize inventory and image-based attribute data, including the widespread k-

732 Nearest Neighbor (k-NN) imputation approach, which preserves the statistical properties

733 among sets of inventory-derived forest attributes (Tomppo, 1991; McRoberts et al.,

734 2007). Additional complexity is introduced when the remote sensing measure itself is a

735 geographic sample, as is the case for current global lidar datasets. In such cases, care

736 must be taken to account for the sampling uncertainty of both the lidar dataset and the

737 forest inventory, as well as the measurement error of lidar-derived structural variables

738 (Healey et al., 2012; Wulder et al., 2012; Nelson et al., 2012).

739 Ecosystem models have leveraged a diverse range of remote sensing datasets in

740 order to initialize parameters and provide validation of retrospective simulations. As

741 discussed above, satellite-derived land cover and fPAR or NDVI are commonly used to

742 parameterize vegetation composition and productivity, respectively, in biogeochemical

743 models (Potter et al., 1993; Running et al., 2004; Zhao et al., 2011). The Ecosystem

744 Demography (ED) model is height structured, and can be initialized using lidar-derived

745 forest heights to constrain carbon uptake (Hurtt et al., 2004). Disturbance information

746 has been incorporated into some ecosystem models. Global fire datasets derived from

747 AVHRR and MODIS have been used to provide $\mathrm{CO}$ and $\mathrm{CO} 2$ fluxes for carbon balance

748 studies (van der Werf et al., 2009). Finer-scale disturbance associated with forest 
749 management has been used in regional-scale modeling studies (Cohen et al., 1996; Masek

750 and Collatz, 2006) or on a sampling basis for the United States (Williams et al., 2012).

751 The recent publication of global maps of forest change at $30 \mathrm{~m}$ resolution (Hansen et al.,

752 2013) allows for global-scale ecosystem models that include actual management

753 dynamics. These observational data sets could be combined with moderate resolution,

754 remotely-sensed vegetation and functional type maps to model ecosystem process

755 dynamics at the level of individual, sub-grid cohorts of unique vegetation type and

756 disturbance history.

757 One example of a model which explicitly combines maps of disturbance history with 758 mapped forest structure and composition is the Forest Carbon Management Framework

759 (ForCaMF), employed by the National Forest System to assess the carbon storage impact

760 of management and different types of natural disturbance. The stand dynamics implied

761 by these layers are linked to empirically calibrated carbon storage functions (Raymond et

762 al., 2015) to enable modeling of storage under historical and hypothetical disturbance

763 regimes. Monte Carlo simulation of error in each of the remote sensing products driving

764 ForCaMF is calibrated directly from inventory data, providing integrated uncertainty

765 estimates (Healey et al,. 2014).

766 In principle, a new generation of diagnostic and prognostic models could be

767 envisioned that would fully leverage the geospatial data available from contemporary

768 remote sensing. Such models operating in a diagnostic mode might operate at the stand,

769 or even the individual scale, and parameterize physiology based on species type and

770 observable functional traits. Photosynthesis could be calculated directly from energy

771 budget approaches via radiative transfer through the canopy, informed by information on 
772 canopy structure, canopy chlorophyll concentration, vegetation fluorescence, and stress

773 indices (including thermal state, activation of the xanthophyll cycle, and pigments

774 indicative of nutrient state). Long-term disturbance dynamics, including attribution of

775 disturbance type and severity, could be parameterized from multispectral time-series

776 combined with three-dimensional structure. Prognostic models of forest response to

777 future climate or management scenarios could also harness remote sensing by

778 confronting model hindcasts with observed, recent changes in vegetation attributes.

779 When combined with in-situ inventory and plot data, such modeling approaches could

780 provide rigorous, physically-based methodologies for scaling forest processes

781

$782 \quad$ Acknowledgements

783 This work was supported by the NASA Terrestrial Ecosystems program and the US

784 Forest Service. Dr. Bruce Cook (NASA GSFC) is thanked for providing the G-LiHT

785 lidar example. 


\section{References}

Ahmed, R., Siqueira, P., and Hensley, S., 2013, A study of forest biomass estimates from lidar in the northern temperate forests of New England, Remote Sensing of Environment, $130,121-135$.

Allen, R.G., Tasumi, M., and Trezza, R., 2007, Satellite-based energy balance for mapping evapotranspiration with internalized calibration (METRIC) - Model. Journal of Irrigation and Drainage Engineering -ASCE, 133, 380-394.

Anderson, M.C., Allen, R.G., Morse, A., and Kustas, W.P., 2012, Use of Landsat thermal imagery in monitoring evapotranspiration and managing water resources. Remote Sensing of Environment, 122, 50-65.

Anderson, M.C., Hain, C., Wardlow, B., Pimstein, A., Mecikalski, J.R., and Kustas, W.P., 2010, Evaluation of Drought Indices Based on Thermal Remote Sensing of Evapotranspiration over the Continental United States. Journal of Climate, 24, 20252044.

Antonova, N., Copass, C., and Clary, S. 2013, Landsat-based monitoring of landscape dynamics in the North Cascades National Park Service Complex: 1985-2009. Natural Resource Data Series NPS/NCCN/NRDS-2013/532. National Park Service, Fort Collins, CO.

Antonarakis, A.S., Saatchi, S.S., Chazdon, R. L., and Moorcroft, P., 2011, Using lidar and radar measurements to constrain forest ecosystem structure and function, Ecological Applications, 21, 1120-1137.

Asner, G.P., 1998, Biophysical and biochemical sources of variability in canopy reflectance, Remote Sensing of Environment, 64, 234-253.

Asner, G.P. and Vitousek, P.M., 2005, Remote analysis of biological invasion and biogeochemical change, Proc. Nat. Acad. Sci., 102, 4383-4386.

Asner G.P. Hyperspectral remote sensing of canopy chemistry, physiology and diversity in tropical rainforests. In: Kalacska M., Sanchez-Azofeifa G.A., editors. Hyperspectral 
Remote Sensing of Tropical and Subtropical Forests. Oxon, UK: Taylor and Francis Group, 2008. pp. 261-288.

Asner, G.P., Martin, R.E., Anderson, C.B., Knapp, D.E., 2015. Quantifying forest canopy traits: Imaging spectroscopy versus field survey. Remote Sensing of Environment 158, $15-27$.

Ayres, M. P. and Lombardero, M. J., 2000, Assessing the consequences of global change for forest disturbance from herbivores and pathogens. Science of the Total Environment, 26, $263-286$.

Azizi, Z., Najafi, A., Sadeghian, S., 2014, Forest road detection using LiDAR data. Journal of Forestry Researc, 25, 975-980.

A. Baccini, Goetz, S J., Walker, W.S. , Laporte, N. T., Sun, M., Sulla-Menashe, D., Hackler, J., Beck, P.S.A. , Dubayah, R., Friedl, M.A., Samanta, S., and Houghton, R. A., 2012, Estimated carbon dioxide emissions from tropical deforestation improved by carbondensity maps. Nature Climate Change, doi:10.1038/nclimate1354.

Baumann, M., Ozdogan, M., Wolter, P.T., Krylov, A., Vladimirova, N., Radeloff, V.C., 2014, Landsat remote sensing of forest windfall disturbance, Remote Sensing of Environment, $143,171-179$.

Bender, E.A., Case, T.J., and Gilpin. M. E., 1984. Perturbation experiments in community ecology: theory and practice. Ecology, 65,1-13.

Bilger W, Schreiber U, Bock M.,1995, Determination of the quantum efficiency of photosystem II and of non-photochemical quenching of chlorophyll fluorescence in the field. Oecologia102,425-432.

Blackard, J.A., Finco, M.V., Helmer, E.H., Holden, G.R., Hoppus, M.L., Jacobs, D.M., Lister, A.J., Moisen, G.G., Nelson, M.D., Riemann, R., Ruefenacht, B., Salajanu, D., Weyermann, D.L., Winterberger, K.C., Brandeis, T.J., Czaplewski, R.L., McRoberts, R.E., Patterson, P.L., Tymcio, R.P., 2008, Mapping U.S. forest biomass using nationwide forest inventory data and moderate resolution information. Remote Sensing of Environment 112, 1658-1677. 
Bounoua, L., Masek, J., and. Tourre, Y.M., 2006, Sensitivity of surface climate to land surface parameters: A case study using the simple biosphere model SiB2, J. Geophys. Res., 111, D22S09, doi:10.1029/2006JD007309.

Clark, M.L., Roberts, D.A., Clark, D.B., 2005, Hyperspectral discrimination of tropical rain forest tree species at leaf to crown scales. Remote Sensing of Environment 96, 375-398.

Chambers, J.Q., Fisher, J.I., Zeng, H., Chapman, E.L., Baker, D.B., \& Hurtt, G.C., 2007, Hurrican Katrina's carbon footprint on U.S. Gulf Coast Forests. Science, 318, 1107.

Chapin III, F. S., Woodwell, G. M., Randerson, J. T., Rastetter, E. B., Lovett, G. M., Baldocchi, D. D., et al., 2006, Reconciling carbon-cycle concepts, terminology, and methods. Ecosystems, 9, 1041-1050.

Chen, F., Mitchell, K., Schaake, J., Xue, Y., Pan, H., Koren, V., Duan, Q.Y., Ek, M., and Betts, A.,1996, Modeling of land surface evaporation by four schemes and comparison with FIFE observations. J. Geophys. Res., 101, 2896-2916.

Cohen, W. B., \& Spies, T. A., 1992, Estimating structural attributes of Douglas-fir/western hemlock forest stands from Landsat and SPOT imagery. Remote Sensing of Environment, 41, 1-17.

Cohen, W., Harmon, M., Wallin, D., and Fiorella, M., 1996, Two decades of carbon flux from forests of the Pacific Northwest, BioScience, 46, 836-844.

Cook, B. D., Corp, L. W., Nelson, R. F., Middleton, E. M., Morton, D. C., McCorkel, J. T., Masek, J. G., Ranson, K. J., Ly, V., and Montesano, P. M., 2013, NASA Goddard's Lidar, Hyperspectral and Thermal (G-LiHT) airborne imager, Remote Sensing, 5, 40454066, doi:10.3390/rs5084045.

Coops, N.C., Waring, R.H., 2001, Estimating forest productivity in the eastern Siskiyou Mountains of southwestern Oregon using a satellite driven process model, 3-PGS. Canadian Journal of Forest Research, 31, 143-154.

d'Oliveira, M.V.N.; Reutebuch, S.E.; McGaughey, R.J.; Andersen, H., 2012, Estimating forest biomass and identifying low-intensity logging areas using airborne scanning lidar in Antimary State Forest, Acre State, Western Brazilian Amazon. Remote Sensing of Environment, 124, 479-491. 
Dale, V. H., Joyce, L. A., Mcnulty, S., Neilson, R. P., Ayres, M. P., Flannigan, M. D., Hanson, P. J., Irland, L. C., Lugo, A. E., Peterson, C. J., Simberloff, D., Swanson, F. J., Stocks, B. J., and Michael Wotton, B., 2001, Climate Change and Forest Disturbances. BioScience, 51, 723.

de Jong, B., Anaya, C., Masera, O., Olguín, M., Paz, F., Etchevers, J., Martínez, R.D., Guerrero, G., Balbontín, C., 2010, Greenhouse gas emissions between 1993 and 2002 from land-use change and forestry in Mexico. Forest Ecology and Management, 260, 1689-1701.

Dolan, K. A., Masek, J. G., Huang, C., and Sun, G., 2009, Regional forest growth measured by combining ICESat GLAS and Landsat data, Journal of Geophysical Research 114(G00E05), doi:10.1029/2008JG000893.

Dolan, K.A., Hurtt, G.C., Chambers, J.Q., Dubayah, R.O., Frolking, S., and Masek, J.G., Using ICESat's Geoscience Laser Altimeter System (GLAS) to assess large-scale forest disturbance caused by hurricane Katrina, Remote Sensing of Environment, 115, 86-96, 2011.

Drolet, G. G., Huemmrich, K. F., Hall, F. G., Middleton, E. M., Black, T. A., Black, T., Barr, A., Barr, A. A., and Margolis, H.: A MODIS-derived photochemical reflectance index to detect inter-annual variations in the photosynthetic light-use efficiency of a boreal deciduous forest, Remote Sensing of Environment, 98, 212-224, doi:10.1016/j.rse.2005.07.006, 2005

Drusch, M., Del Bello, U., Carlier, S., Colin, O., Fernandez, V. et al. (2012) Sentinel-2: ESA's Optical High-Resolution Mission for GMES Operational Services, Remote Sensing of Environment, 120, 25-36.

Dubayah. R.O., S.L. Sheldon, D.B. Clark, M.A. Hofton, J.B. Blair, G.C. Hurtt, and R.L Chazdon, 2010, Estimation of tropical forest height and biomass dynamics using lidar remote sensing at La Selva, Costa Rica, Journal of Geophysical Research, 115, 10.1029/2009JG000933

Eidenshink, J., Schwind, B., Brewer, K., Zhu, Z., Quayle, B., Howard, S., 2007. A Project for Monitoring Trends in Burn Severity. Fire Ecology, 3, 3-21. 
Farquhar, G. D., von Caemmerer, S. V., \& Berry, J. A.,1980, A biochemical model of photosynthetic CO2 assimilation in leaves of C3 species. Planta, 149, 78-90.

Fisher, J.B., Tu, K.P., Baldocchi, D.D., 2008, Global estimates of the land-atmosphere water flux based on monthly AVHRR and ISLSCP-II data, validated at 16 FLUXNET sites. Remote Sensing of Environment 112, 901-919.

Fisher, J.B., Huntzinger, D.N., Schwalm, C.R., Sitch, S., 2014. Modeling the Terrestrial Biosphere. Annu Rev Env Resour 39, 91-123.

Frolking, S., Palace, M. W., Clark, D. B., Chambers, J. Q., Shugart, H. H., and Hurtt, G. C., 2009, Forest disturbance and recovery: A general review in the context of spaceborne remote sensing of impacts on aboveground biomass and canopy structure. Journal of Geophysical Research, 114(G2), 1-27.

Galford, G.L., Melillo, J.M., Kicklighter, D.W., Mustard, J.F., Cronin, T.W., Cerri, C.E.P., Cerri, C.C., 2010, Historical carbon emissions and uptake from the agricultural frontier of the Brazilian Amazon. Ecol Appl 21, 750-763.

Garbulsky, M. F., Penuelas, J., Gamon, J., Inoue, Y. \& Filella, I., 2011, The photochemical reflectance index (PRI) and the remote sensing of leaf, canopy and ecosystem radiation use efficiencies A review and meta-analysis. Remote Sensing of Environment, 115, 281297.

Garcı-Haro, F. J., Gilabert, M. A., and Melia, J., 2001, Monitoring fire-affected areas using Thematic Mapper data. International Journal of Remote Sensing, 22(4):533-549.

Garren, K. H., 1943, Effects of fire on vegetation of the southeastern United States, Botanical Review, 9, 617-654.

Gitay, H. \& Noble, I.R., 1997, What are functional types and how should we seek them? In: Smith, T.M., Shugart, H.H. \& Woodward, F.I. (eds.) Plant Functional Types: their relevance to ecosystem properties and global change, pp. 3-19. Cambridge University Press, Cambridge.

Godron, M., \& Forman, R. T. T., 1983, Landscape modification and changing ecological characteristics. In Disturbance and ecosystems (pp. 12-28). Springer Berlin Heidelberg. 
Goerner, A., Reichstein, M., Tomelleri, E., Hanan, N., Rambal, S., Papale, D., Dragoni, D. \& Schmullius, C., 2011, Remote sensing of ecosystem light use efficiency with MODISbased PRI. Biogeosciences, 8, 189-202.

Goetz, S. J., Bond-Lamberty, B. Hicke, ,J. A., Houghton, R. A., McNulty, S., O'Halloran, T., Meddens, A. J. H., Pfeifer, E. M., Midrexler, D., and Kasischke, E. S., 2012, Observations and assessment of forest carbon recovery following disturbance in North America, J. Geophy. Res., 117, G02022, doi:10.1029/2011JG001733.

Goodwin, N. R., Coops, N. C., Wulder, M. A., Gillanders, S., Schroeder, T. A., and Nelson, T., 2008, Estimation of insect infestation dynamics using a temporal sequence of Landsat data. Remote Sensing of Environment, 112, 3680-3689.

Goward, S. N., Masek, J. G., Cohen, W., Moisen, G., Collatz, G. J., Healey, S., Houghton, R. A., Huang, C., Kennedy, R., Law, B., Powell, S., Turner, D., and Wulder, M. A.,2008, Forest disturbance and North American carbon flux. Eos, Transactions of the American Geophysical Union, 89, 105.

Gower, S. T., Kucharik, C. J. \& Norman, J. M., 1999, Direct and indirect estimation of leaf area index, fAPAR and net primary production of terrestrial ecosystems. Remote Sensing of Environment, 70, 29-51.

Grace, J., Nichol, C., Disney, M., Lewis, P., Quaife, T. \& Bowyer, P., 2007, Can we measure terrestrial photosynthesis from space directly, using spectral reflectance and fluorescence? Global Change Biology, 13, 1484-1497.

Guindon, L., P.Y. Bernier, A. Beaudoin, D. Pouliot, P. Villemaire, R.J. Hall, R. Latifovic, R. St-Amant. Annual mapping of large forest disturbances across Canada's forests using 250 m MODIS imagery from 2000 to 2011. Canadian Journal of Forest Research, 2014, 44:1545-1554, 10.1139/cjfr-2014-0229.

Gutiérrez-Vélez, V. H., and DeFries, R., 2013, Annual multi-resolution detection of land cover conversion to oil palm in the Peruvian Amazon. Remote Sensing of Environment 129:154-167.

Hall, F.G., Bergen, K., Blair, J.B., Dubayah, R., Houghton, R., Hurtt, G., Kellendorfer, J., Lefsky, M., Ranson, J., Saatchi, S., Shugart, H.H., and Wickland, D., 2011, 
Characterizing 3D vegetation structure from space: Mission requirements, Remote Sensing of Environment, 115, 2753-2775.

Hall, R. J., Skakun, R. S., Arsenault, E. J., \& Case, B. S., 2006, Modeling forest stand structure attributes using Landsat ETM+data: Application to mapping of aboveground biomass and stand volume. Forest Ecology and Management, 225, 378 - 390.

Hansen, M.C., P. V. Potapov, R. Moore, M. Hancher, S.A. Turubanova, A. Tyukavina, D. Thau, S.V. Stehman, S.J. Goetz, T.R. Loveland, A. Komardeey, A. Egorov, L. Chini, C.O. Justice, and J.R.G. Townshend, 2013, High-Resolution Global Maps of 21stCentury Forest Cover Change. Science 342, 850-853

Hargrove, W.W., Hoffman, F.M., Law, B.E., 2003. New analysis reveals representativeness of the AmeriFlux network. Eos, Transactions American Geophysical Union 84, 529-535.

Hargrove, WW., Spruce, J.P., Gasser, G.E., and Hoffman, F.M., 2009, Toward a national early warning system for forest disturbances using remotely sensed canopy phenology, Photogrammetric Engineering and Remote Sensing, 75, 1150-1156.

Hayes, D.J. and Sader, S.A., 2001, Change detection techniques for monitoring forest clearing and regrowth in a tropical moist forest, Photogrammetric Engineering and Remote Sensing, 67, 1067-1075.

Hayes, D., Turner, D., 2012. The need for "apples-to-apples" comparisons of carbon dioxide source and sink estimates. Eos Trans. AGU 93.

Hayes, D.J., McGuire, A.D., Kicklighter, D.W., Gurney, K.R., Burnside, T.J., Melillo, J.M., 2011, Is the northern high-latitude land-based CO2 sink weakening? Global Biogeochemical Cycles, 25, GB3018.

Hayes, D.J., Turner, D.P., Stinson, G., McGuire, A.D., Wei, Y., West, T.O., Heath, L.S., de Jong, B., McConkey, B.G., Birdsey, R.A., Kurz, W.A., Jacobson, A.R., Huntzinger, D.N., Pan, Y., Post, W.M., Cook, R.B., 2012, Reconciling estimates of the contemporary North American carbon balance among terrestrial biosphere models, atmospheric inversions, and a new approach for estimating net ecosystem exchange from inventorybased data. Global Change Biology 18, 1282-1299. 
Healey, S.P., Cohen, W.B., Spies, T.A., Moeur, M., Pflugmacher, D., Whitley, M.G., and Lefsky, M., 2008, The Relative Impact of Harvest and Fire upon Landscape-Level Dynamics of Older Forests: Lessons from the Northwest Forest Plan. Ecosystems, 11, 1106 DOI: 10.1007/s10021-008-9182-8

Healey, S.P., Patterson, P.L., Saatchi, S.S., Lefsky, M.A., Lister, A.J., \& Freeman, E.A., 2012, A sample design for globally consistent biomass estimation using lidar data from the Geoscience Laser Altimeter System (GLAS). Carbon Balance and Management, 7, doi:10.1186/1750-0680-7-10

Healey, S.P., Urbanski, S.P., Patterson, P.L., and Garrard, C., 2014, A framework for simulating map error in ecosystem models. Remote Sensing of Environment, 150, 207217

Heath, L.S., Smith, J.E., Skog, K.E., Nowak, D.J., Woodall, C.W., 2011, Managed Forest Carbon Estimates for the US Greenhouse Gas Inventory, 1990-2008. J Forest, 109, $167-$ 173.

Heinsch, F. A., Zhao, M., Running, S., Kimball, J. S., Nemani, R., Davis, K., Bolstad, P., Cook, B., Desai, A., Ricciuto, D., Law, B. E., Oechel, W., Kwon, H., Luo, H., Wofsy, S., Dunn, A., Munger, J. W., Baldocchi, D., Xu, L., Hollinger, D., Richardson, A. D., Stoy, P., Siqueira, M., Monson, R., Burns, S. \& Flanagan, L. B., 2006, Evaluation of remote sensing based terrestrial productivity from MODIS using regional tower Eddy Flux Netowrk Observations. IEEE Transactions on Geosciences and Remote Sensing, 44, 1908-1925.

Helmer, E. H., Lefsky, M. A., and Roberts, D. A., 2009, Biomass accumulation rates of Amazonian secondary forest and biomass of old-growth forests from Landsat time series and the Geoscience Laser Altimeter System. Journal of Applied Remote Sensing, 3, 033505.

Hicke, J. A., Allen, C. D., Desai, A. R., Dietze, M. C., Hall, R. J., Ted Hogg, E. H., Kashian, D. M., Moore, D., Raffa, K. F., Sturrock, R. N., and Vogelmann, J., 2012, Effects of biotic disturbances on forest carbon cycling in the United States and Canada. Global Change Biology, 18, 7-34. 
Hilker, T., Wulder, M.A., Coops, N.C., Linke, J., McDermid, G., Masek, J., Gao, F., \& White, J.C., 2009, A new data fusion model for high spatial- and temporal- resolution mapping of forest disturbance based on Landsat and MODIS. Remote Sensing of Environment, 113, 1613-1627.

Hilker, T., Coops, N.C., Hall, F.G., Nichol, C.J, Lyapustin, A., Black, T.A., Wulder, M.A., Leuning, R., Barr, A., Hollinger, D.Y., Munger, J. W., Tucker, C. J., 2011, Inferring terrestrial photosynthetic light use efficiency of temperate ecosystems from space. Journal of Geophysical Research. Vol. 116, G03014.

Holmgren, P. and Thuresson, T.,1998, Satellite remote sensing for forestry planning - A review. Scandinavian Journal of Forest Research, 13, 90-110.

Houghton, R.A., Hobbie, J.E., Melillo, J.M., Moore, B., Peterson, B.J., Shaver, G.R., Woodwell, G.M., 1983, Changes in the Carbon Content of Terrestrial Biota and Soils between 1860 and 1980: A Net Release of CO"2 to the Atmosphere. Ecol Monogr 53, 235-262.

Houghton, R. A.,2003, Why are estimates of the terrestrial carbon balance so different?. Global Change Biology, 9, 500-509.

Huang, C.Q., Goward, S.N., Masek, J.G., Thomas, N., Zhu, Z.L., and Vogelmann, J.E., 2010, An automated approach for reconstructing recent forest disturbance history using dense Landsat time series stacks, Remote Sensing of Environment, 114, 183-198.

Hudiburg, T., Law, B. , Turner, D.P., Campbell, J., Donato, D., and Duane, M., 2009, Carbon dynamics of Oregon and Northern California forests and potential land-based carbon storage. Ecological Applications, 19, 163-180.

Hughes, M.J., 2014, "New Remote Sensing Methods for Detecting and Quantifying Forest Disturbance and Regeneration in the Eastern United States. " PhD diss., University of Tennessee.

Huntzinger, D.N., Post, W., Wei, Y., Michalak, A., West, T., Jacobson, A., Baker, I., Chen, J., Davis, K., Hayes, D., Hoffman, F., Jain, A., Liu, S., McGuire, A., Neilson, R., Potter, C., Poulter, B., Price, D., Raczka, B., Tian, H., Thornton, P., Tomelleri, E., Viovy, N., Xiao, J., Yuan, W., Zeng, N., Zhao, M., Cook. R., 2012, North American Carbon Program 
(NACP) regional interim synthesis: terrestrial biospheric model intercomparison, Ecological Modelling, 232, 144-157.

Huntzinger, D.N., Schwalm, C., Michalak, A.M., Schaefer, K., King, A.W., Wei, Y., Jacobson, A., Liu, S., Cook, R.B., Post, W.M., Berthier, G., Hayes, D., Huang, M., Ito, A., Lei, H., Lu, C., Mao, J., Peng, C.H., Peng, S., Poulter, B., Riccuito, D., Shi, X., Tian, H., Wang, W., Zeng, N., Zhao, F., Zhu, Q., 2013, The North American Carbon Program Multi-scale synthesis and Terrestrial Model Intercomparison Project - Part 1: Overview and experimental design. Geosci. Model Dev. Discuss, 6, 3977-4008.

Hurtt, G.C., Dubayah, R., Drake, J., Moorcroft, P.R., Pacala, S.W., Blair, J.B., Fearon, M.G., 2004, Beyond potential vegetation: Combining lidar data and a height-structured model for carbon studies, Ecological Applications, 14, 873-883.

Imhoff, M., 1995, Radar backscatter and biomass saturation: ramifications for global biomass inventory, IEEE Trans. Geosci. and Remote Sens., 33, 511-518.

Jain, A.K., Yang, X., 2005, Modeling the effects of two different land cover change data sets on the carbon stocks of plants and soils in concert with $\mathrm{CO} 2$ and climate change, Global Biogeochem Cycles, 19, GB2015.

Jensen, J. R., 2009, Remote sensing of the environment: An earth resource perspective 2/e. Pearson Education India.

Joiner, J., Yoshida, Y., Vasilkov, A. P., Yoshida, Y., Corp, L. A., and Middleton, E. M., 2011, First observations of global and seasonal terrestrial chlorophyll fluorescence from space, Biogeosciences, 8, 637-651, doi:10.5194/bg-8-637-2011.

Jung, M., Henkel, K., Herold, M., Churkina, G., 2006, Exploiting synergies of global land cover products for carbon cycle modeling, Remote Sensing of Environment, 101, 534553.

Jung, M., Reichstein, M., Margolis, H.A., Cescatti, A., Richardson, A.D., Arain, M.A., Arneth, A., Bernhofer, C., Bonal, D., Chen, J., Gianelle, D., Gobron, N., Kiely, G., Kutsch, W., Lasslop, G., Law, B.E., Lindroth, A., Merbold, L., Montagnani, L., Moors, E.J., Papale, D., Sottocornola, M., Vaccari, F., Williams, C., 2011, Global patterns of land-atmosphere fluxes of carbon dioxide, latent heat, and sensible heat derived from 
eddy covariance, satellite, and meteorological observations. J. Geophys. Res. 116, G00J07.

Justice, C.O., Townshend, J.R.G., Holben, B.N.,and Tucker, C.J.,1985, Analysis of the phenology of global vegetation using meterological satellite data, International Journal of Remote Sensing, 6, 1271-1318.

Justice, C. O., Townshend, J. R. G., Vermote, E. F., Masuoka, E., Wolfe, R. E., Saleous, N., Roy, D. P., and Morisette. J. T., 2002. An overview of MODIS Land data processing and product status. Remote sensing of Environment, 83, 3-15.

Kasischke, E.S., 2004, Continental-Scale Partitioning of Fire Emissions During the 1997 to 2001 El Niño/La Niña Period, Science, 303, 73-76.

Keeley, J. E. ,2009, Fire intensity, fire severity and burn severity: A brief review and suggested usage, Int. J. Wildland Fire, 18, 116-126.

Kellndorfer, J.M., Walker, W.S., Pierce, L.E., Dobson, M.C., Fites, J., \& Hunsaker, C., 2004, Vegetation height derivation from Shuttle Radar Topography Mission and National Elevation data sets. Remote Sensing of Environment, 93, 339-358.

Kennedy, R.E., W.B. Cohen, T.A. Schroeder, 2007, Trajectory-based change detection for automated characterization of forest disturbance dynamics, Remote Sensing of Environment, 110,370-386.

Kimball, J.S., Keyser, A.R., Running, S.W., Saatchi, S.S., 2000, Regional assessment of boreal forest productivity using an ecological process model and remote sensing parameter maps. Tree Physiology, 20, 761-775.

King, D. A., Turner, D. P., and Ritts, W. D., 2011, Parameterization of a diagnostic carbon cycle model for continental scale application. Remote Sensing of Environment, 115, 1653-1664.

Knyazikhin Y, et al., 2013, Hyperspectral remote sensing of foliar nitrogen content. Proceedings of the National Academy of Sciences, 110, E185-E192. 
Kokaly, R.F., Asner, G. P., Ollinger, S. V., Martin, M. E., and Wessman, C. A., 2008, Characterizing canopy biochemistry from imaging spectroscopy and its application to ecosystem studies. Remote Sensing of Environment, 113, doi:10.1016/j.rse.2008.10.018

Koster, R. D., and Suarez, M. J.,1992, Modeling the land surface boundary in climate models as a composite of independent vegetation stands, Journal of Geophysical Research, 97, 2697-2715.

Krieger, D. J., 2001, The economic value of forest ecosystem services: a review. Washington, DC, USA: Wilderness Society.

Kurz, W.A., Dymond, C.C., White, T.M., Stinson, G., Shaw, C.H., Rampley, G.J., Smyth, C., Simpson, B.N., Neilson, E.T., Trofymow, J.A., Metsaranta, J., Apps, M.J., 2009, CBMCFS3: A model of carbon-dynamics in forestry and land-use change implementing IPCC standards. Ecological Modelling, 220, 480-504.

Landsberg, J. J., and Waring, R. H., 1997, A generalised model of forest productivity using simplified concepts of radiation-use efficiency, carbon balance and partitioning. Forest Ecology and Management, 95, 209-228.

le Maire, G., Dupuy, S., Nouvellon, Y., Loos, R.A., Hakamada, R., 2014, Mapping shortrotation plantations at regional scale using MODIS time series: Case of eucalypt plantations in Brazil, Remote Sensing of Environment, 152, 136-149.

Lim, K.P., Treitz, P., Wulder, M.A., St-Onge, B.A., Flood, M., 2003, LiDAR remote sensing of forest structure, Progress in Physical Geography, 27, 88-106.

Loveland, T. R., Reed, B. C., Brown, J. F., Ohlen, D. O., Zhu, Z., Yang, L., \& Merchant, J. W., 2000, Development of a global land cover characteristics database and IGBP DISCover from 1 km AVHRR data. International Journal of Remote Sensing, 21, 13031365.

Loew, A., van Bodegom, P. M., Widlowski, J.-L., Otto, J., Quaife, T., Pinty, B., and Raddatz, T., 2014, Do we (need to) care about canopy radiation schemes in DGVMs? Caveats and potential impacts, Biogeosciences, 11, 1873-1897, doi:10.5194/bg-11-18732014. 
Lu, D., 2006, The potential and challenge of remote sensing-based biomass estimation. International Joirnal of Remote Sensing, 27, 1297-1328.

Luo, Y., Ogle, K., Tucker, C., Fei, S., Gao, C., LaDeau, S., Clark, J.S., Schimel, D.S., 2011, Ecological forecasting and data assimilation in a data-rich era. Ecological Applications, $21,1429-1442$.

Luo, Y.Q., Randerson, J.T., Abramowitz, G., Bacour, C., Blyth, E., Carvalhais, N., Ciais, P., Dalmonech, D., Fisher, J.B., Fisher, R., Friedlingstein, P., Hibbard, K., Hoffman, F., Huntzinger, D., Jones, C.D., Koven, C., Lawrence, D., Li, D.J., Mahecha, M., Niu, S.L., Norby, R., Piao, S.L., Qi, X., Peylin, P., Prentice, I.C., Riley, W., Reichstein, M., Schwalm, C., Wang, Y.P., Xia, J.Y., Zaehle, S., Zhou, X.H., 2012, A framework for benchmarking land models. Biogeosciences, 9, 3857-3874.

McConnel, T. J., Johnson, E. W., and Burns, B., 2000, A Guide to Conducting Aerial sketchmapping Surveys FHTET 00-01. USDA Forest Service, Fort Collins Colorodo.

McRoberts., R.E. and E.O. Tomppo, 2007, Remote sensing support for national forest inventories, Remote Sensing of Environment, 110, 412-419.

Mao, J., Shi, X., Thornton, P.E., Piao, S., Wang, X., 2012, Causes of spring vegetation growth trends in the northern mid-high latitudes from 1982 to 2004, Environmental Research Letters 7, 014010.

Mao, J., Thornton, P.E., Shi, X., Zhao, M., Post, W.M., 2012, Remote Sensing Evaluation of CLM4 GPP for the Period 2000-09, Journal of Climate 25, 5327-5342.

Margono, Belinda A., et al., 2012, Mapping and Monitoring Deforestation and Forest Degradation in Sumatra (Indonesia) Using Landsat Time Series Data Sets from 1990 to 2010. Environmental Research Letters, 7. doi: 10.1088/1748-9326/7/3/034010.

Marsden, C., le Maire, G., Stape, J-L., Seen, D.L., Roupsard, O., Cabral, O., Epron, D., Lima, A.M.N., Nouvellon, Y., 2010, Relating MODIS vegetation index time series with structure, light absorption, and stem production of fast-growing Eucalyptus plantations, Forest Ecology and Management, 259, 1741-1753. 
Marshall, M., Tu, K., Funk, C., Michaelsen, J., Williams, P., Williams, C., Ardö, J., Boucher, M., Cappelaere, B., de Grandcourt, A., Nickless, A., Nouvellon, Y., Scholes, R., and Kutsch, W., 2013, Improving operational land surface model canopy evapotranspiration in Africa using a direct remote sensing approach. Hydrol. Earth Syst. Sci., 17, 1079-1091.

Masek, J.G., and Collatz, G.J., 2006, Estimating forest carbon fluxes in a disturbed southeastern landscape: Integration of remote sensing, forest inventory, and biogeochemical modeling, J. Geophys. Res., 111(G01006), doi:10.1029/2005JG000062

Masek, J. G., Huang, C., Wolfe, R., Cohen, W., Hall, F., Kutler, J., and Nelson, P., 2008, North American forest disturbance mapped from a decadal Landsat record. Remote Sensing of Environment, 112, 2914-2926.

Matthews, E., 1983: Global vegetation and land use: New high-resolution data bases for climate studies. J. Clim. Appl. Meteorol, 22, 474-487.

Medvigy, D., Wofsy, S.C., Munger, J.W., Hollinger, D.Y., Moorcroft, P.R., 2009, Mechanistic scaling of ecosystem function and dynamics in space and time: Ecosystem Demography model version 2, Journal of Geophysical Research - Biogeosciences, 114, G01002.

Melillo, J. M., McGuire, A. D., Kicklighter, D. W., Moore, B., Vorosmarty, C. J., \& Schloss, A. L.,1993, Global climate change and terrestrial net primary production. Nature, 363, 234-240.

Melton, J.R., and Arora, V.K., 2014, Sub-grid scale representation of vegetation in global land surface schemes: implications for estimation of the terrestrial carbon sink, Biogeosciences, 11, 1021-1036.

Mitchard, E.T.A., Feldpausch, T.R., Brienen, R.J.W., et al., 2014, Markedly divergent estimates of Amazon forest carbon density from ground plots and satellites. Global Ecology and Biogeography, 23, 935-946

Milesi, C., Hashimoto, H., Running, S. W. \& Nemani, R. R., 2005, Climate variability, vegetation productivity and people at risk, Global and Planetary Change, 47, 221-231.

Millennium Ecosystem Assessment, 2005. Ecosystems and Human Well-Being: Synthesis. Island Press, Washington. 155pp. 
Minh, D.H.T., Le Toan, T., Rocca, F., Tebaldini, S., d'Alessandro, M.M., and Villard, L., 2014, Relating P-band synthetic aperture radar tomography to tropical forest biomass, IEEE Trans. Geosci. and Remote Sens., 52, 967-979.

Mu, Q., Zhao, M., and Running, S.W., 2011, Improvements to a MODIS global terrestrial evapotranspiration algorithm. Remote Sensing of Environment, 115, 1781-1800.

Myneni, R. B., Hoffman, S., Knyazikhin, Y., Privette, J. L., Glassy, J., Tian, Y., Wang, Y., Song, X., Zhang, Y., Smith, G. R., Lotsch, A., Friedl, M., Morisette, J. T., Votava, P., Nemani, R. R. \& Running, S. W., 2002, Global products of vegetation leaf area and fraction absorbed PAR from year one of MODIS data, Remote Sensing of Environment, $83,214-231$.

Nakaji, T., Ide, R., Takagi, K., Kosugi, Y., Ohkubo, S., Nasahara, K. N., Saigusa, N. \& Oguma, H., 2008, Utility of spectral vegetation indices for estimation of light conversion efficiency in coniferous forests in Japan. Agricultural and Forest Meteorology, 148, 776787.

Neigh, C.S.R., Nelson, R.F., Ranson, K.J., Margolis, H.A., Montesano, P.M., Sun, G., Kharuk, V., Naesset, E., Wulder, M.A., Anderson, H.E., 2013, Taking stock of circumboreal forest carbon with ground measurements, airborne, and spaceborne LiDAR. Remote Sensing of Environment, 137, 274-287.

Nelson, R.F., T. Gobakken, E. Naesset, Gregoire, T.G., Stahl, G., Holm, S., Flewelling, J., 2012, Lidar sampling - Using an airborne profiler to estimate forest biomass in Hedmark County, Norway, Remote Sensing of Environment, 123, 563-578.

Nemani, R. R., Keeling, C. D., Hashimoto, H., Jolly, W. M., Piper, S. C., Tucker, C. J., Myneni, R. B. \& Running, S. W., 2003, Climate-driven increases in global terrestrial net primary production from 1982 to 1999 . Science, $300,1560-1563$.

Ohmann, J. L. \& Gregory, M. J., 2002, Predictive mapping of forest composition and structure with direct gradient analysis and nearest-neighbor imputation in coastal Oregon, U.S.A., Canadian Journal of Forest Research, 32, 725-741. 
Ohmann, J. L., Gregory, M. J., Roberts, H. M., Cohen, W. B., Kennedy, R. E. \& Yang, Z. Q., 2012, Mapping change of older forest with nearest-neighbor imputation and Landsat time-series. Forest Ecology and Management, 272, 13-25.

Ohmann, J.L., Gregory, M.J., Roberts, H.M., 2014, Scale considerations for integrating forest inventory plot data and satellite image data for regional forest mapping. Remote Sensing of Environment, 151, 3-15.

Ollinger, S., Smith, M.-L., 2005, Net Primary Production and Canopy Nitrogen in a Temperate Forest Landscape: An Analysis Using Imaging Spectroscopy, Modeling and Field Data. Ecosystems, 8, 760-778.

O'Neill, R.V., Krummel, J.R., Gardner, R.H., Sugihara, G., Jackson, B., DeAngelis, D.L., Milne, B.T., Turner, M.G., Zygmunt, B., Christensen, S.W., Dale, V.H. and Graham, R.L., 1988, Indices of landscape pattern. Landscape Ecology, 1, 153-162.

Orwig, D. A., Thompson, J. R., Povak, N., Manner, M., Niebyl, D., and Foster, D. R., 2012, A foundation tree at the precipice: Tsuga canadensis health after the arrival of Adelges tsugae in central New England. Ecosphere, 3, 1-16.

Oumar, Z. and Mutanga, O., 2011, The potential of remote sensing technology for the detection and mapping of Thaumastocoris peregrinus in plantation forests. Southern Forests: a Journal of Forest Science, 73, 23-31.

Palmer, W.C., 1965, Meteorological drought. In U.S.W. Bureau (Ed.) (p. 65 pp.)

Pan, Y., Birdsey, R.A., Fang, J., et al., 2011, A large and persistent carbon sink in the world's forests, Science, 333, 988-993.

Parazoo, N. C., Bowman, K., Fisher, J. B., Frankenberg, C., Jones, D. B. A., Cescatti, A., Perez-Priego, O., Wohlfahrt, G. \& Montagnani, L., 2014, Terrestrial gross primary production inferred from satellite fluorescence and vegetation models. Global Change Biology, 20, 3103-3121.

Peres, C. A., Barlow, J., Laurance, W.F., 2006, Detecting anthropogenic disturbance in tropical forests. Trends in Ecology \& Evolution, 21, 227-229 
Pflugmacher, D., Cohen, W.B., and Kennedy, R.E., 2012, Using Landsat-derived disturbance history (1972-2010) to predict current forest structure, Remote Sensing of Environment, $122,146-165$.

Pickett, S.T.A., and P.S. White. 1985. The Ecology of Natural Disturbance and Patch Dynamics. Academic Press, Orlando FL.

Potter, C.S., Randerson, J.T., Field, C.B., Matson, P.A., Vitousek, P.M., Mooney, H.A., Klooster, S.A., 1993, Terrestrial ecosystem production: A process model based on global satellite and surface data. Global Biogeochem Cycles, 7, 811-841.

Powell, S.L., Cohen, W.B., Healey, S.P., Kennedy, R.E., Moisen, G.G., Pierce, K.B., \& Ohmann, J.L., 2010, Quantification of live aboveground forest biomass dynamics with Landsat time-series and field inventory data: A comparison of empirical modeling approaches. Remote Sensing of Environment, 114, 1053-1068

Quaife, T., Lewis, P., De Kauwe, M., Williams, M., Law, B. E., Disney, M., \& Bowyer, P., 2008, Assimilating canopy reflectance data into an ecosystem model with an Ensemble Kalman Filter. Remote Sensing of Environment, 112, 1347-1364.

Quillet, A., Peng, C., Garneau, M., 2010, Toward dynamic global vegetation models for simulating vegetation-climate interactions and feedbacks: recent developments, limitations, and future challenges, Environmental Reviews, 18, 333-353.

Raymond, C.L., Healey, S., Peduzzi, A., \& Patterson, P., 2015, Representative regional models of post-disturbance forest carbon accumulation: Integrating inventory data and a growth and yield model. Forest Ecology and Management, 336, 21-34

Rayner, P. J., Scholze, M., Knorr, W., Kaminski, T., Giering, R., \& Widmann, H., 2005, Two decades of terrestrial carbon fluxes from a carbon cycle data assimilation system (CCDAS). Global Biogeochemical Cycles, 19, DOI:10.1029/2004GB002254.

Richardson, A., J. Jenkins, B. Braswell, D. Hollinger, S. Ollinger, M.-L. Smith, 2007, Use of digital webcam images to track spring green-up in a deciduous broadleaf forest, Oecologia, 152, 323-334

Richardson, A., Williams, M., Hollinger, D., Moore, D.P., Dail, D.B., Davidson, E., Scott, N., Evans, R., Hughes, H., Lee, J., Rodrigues, C., Savage, K., 2010, Estimating parameters of 
a forest ecosystem $\mathrm{C}$ model with measurements of stocks and fluxes as joint constraints. Oecologia, 164, 25-40.

Roberts, D.A., Gardner, M., Church, R., Ustin, S., Scheer, G., and Green, R.O., 1998, Mapping chaparral in the Santa Monica Mountains using multiple endmember spectral mixture models, Remote Sensing of Environment, 65, 267-279.

Rosette, J., Cook, B., Nelson, R., Huang, C., Masek, J., Tucker, C., Sun, G., Huang, W. ; Montesano, P., Rubio-Gil, J., Ranson, J., 2015, Sensor Compatibility for Biomass Change Estimation Using Remote Sensing Data Sets: Part of NASA's Carbon Monitoring System Initiative, IEEE Geoscience and Remote Sensing Letters, in press.

Running, S. W., Baldocchi, D. D., Turner, D. P., Gower, S. T., Bakwin, P. S. and Hibbard, K. A.,1999, A global terrestrial monitoring network integrating tower fluxes, flask sampling, ecosystem modeling and EOS satellite data. Remote Sensing of Environment, 70, 108128.

Running, S.W., Nemani, R.R., Heinsch, F.A., Zhao, M., Reeves, M., Hashimoto, H., 2004. A Continuous Satellite-Derived Measure of Global Terrestrial Primary Production,. Bioscience, 54, 547-560.

Ryan C.M., Hill, T., Woollen, E., Ghee, C., Mitchard, E., Cassells, G., et al., 2012, Quantifying small-scale deforestation and forest degradation in African woodlands using radar imagery, Global Change Biology, 18, 243-257.

Saatchi, S. S., Harris, N. L., Brown, S., Lefsky, M., Mitchard, E. T. A., Salas, W., ... Morel, A., 2011, Benchmark map of forest carbon stocks in tropical regions across three continents, Proceedings of the National Academy of Sciences, 108, 9899-9904.

Santos, C. and Messina, J.P., 2008, The Integration of Ground-Based Digital Video and Synthetic Aperture Radar for Spatio-Temporal Modeling of African Palm in the Ecuadorian, Amazon. Photogrammetric Engineering and Remote Sensing. 74, 711-723

Schaefer, K., Schwalm, C.R., Williams, C., Arain, M.A., Barr, A., Chen, J.M., Davis, K.J., Dimitrov, D., Hilton, T.W., Hollinger, D.Y., Humphreys, E., Poulter, B., Raczka, B.M., Richardson, A.D., Sahoo, A., Thornton, P., Vargas, R., Verbeeck, H., Anderson, R., Baker, I., Black, T.A., Bolstad, P., Chen, J., Curtis, P.S., Desai, A.R., Dietze, M., 
Dragoni, D., Gough, C., Grant, R.F., Gu, L., Jain, A., Kucharik, C., Law, B., Liu, S., Lokipitiya, E., Margolis, H.A., Matamala, R., McCaughey, J.H., Monson, R., Munger, J.W., Oechel, W., Peng, C., Price, D.T., Ricciuto, D., Riley, W.J., Roulet, N., Tian, H., Tonitto, C., Torn, M., Weng, E., Zhou, X., 2012, A model-data comparison of gross primary productivity: Results from the North American Carbon Program site synthesis. Journal of Geophysical Research: Biogeosciences, 117, G03010.

Scheffer, M., Westley, F., Brock, W.A., and Holmgren, M., 2002, Dynamic Interaction of Societies and Ecosystems - Linking Theories from Ecology, Economy, and Sociology in Lance H Gunderson and C.S. Holling (eds) Panarchy. Island Press, Washington DC.

Schimel, D., Stephens, B., and Fisher, J.B., 2015, Effect of increasing CO2 on the terrestrial carbon cycle, Proceedings of the National Academy of Sciences, doi:10.1073/ pnas. 1407302112

Schroeder, T.A., Wulder, M.A., Healey, S.P., and Moisen, G.G., 2011, Mapping wildfire and clearcut harvest disturbances in boreal forests with Landsat time series data, Remote Sensing of Environment, 115, 1421-1433.

Sonnentag, O., K. Hufkens, C. Teshera-Sterne, A.M. Young, M. Friedl, B.H. Braswell, T. Milliman, J. O’Keefe, and A.D. Richardson. 2012. Digital repeat photography for phenological research in forest ecosystems. Agricultural and Forest Meteorology, 152: 159-177.

Sousa, W.P. 1984. The role of distubance in natural communities. Annula Review of Ecological Systems 15:535-591.

Ståhl, G., Holm, S., Gregoire, T.G., Gobakken, T., Naesset, E., \& Nelson, R. (2010). Modelbased inference for biomass estimation in a LiDAR sample survey in Hedmark County, Norway. Canadian Journal of Forest Resources, 41, 96-107.

Su, Z., 2002, The Surface Energy Balance System (SEBS) for estimation of turbulent heat fluxes. Hydrol. Earth Syst. Sci., 6.

Thenkabail, P.S., Stucky, N., Griscom, B.W., Ashton, M.S., Diels, J., Van Der Meer, B., and Enclona, E. 2004. Biomass estimations and carbon Stock calculations in the oil palm 
plantations of African derived savannas using IKONOS data, International Journal of Remote Sensing. International Journal of Remote Sensing. 25(23):5447-5472.

Thomas, N.E., Huang, C., Goward, S.N., Powell, S., Rishmawi, K., Schleeweis, K., and Hinds, A. (2011). Validation of North American forest dynamics derived from Landsat time series stacks. Remote Sensing of Environment, 115, 19-32.

Thomas, R.Q., Hurtt, G.C., Dubayah, R., Schilz, M.H., 2008, Using lidar data and a heightstructured ecosystem model to estimate forest carbon stocks and fluxes over mountainuous terrain, Canadian Journal of Remote Sensing, 34, S351-S363.

Thornton, P. E., Law, B. E., Gholz, H. L., Clark, K. L., Falge, E., Ellsworth, D. S., Goldstein, A. H., Monson, R. K., Hollinger, D., Falk, M., Chen, J. \& Sparks, J. P. (2002) Modeling and measuring the effects of disturbance history and climate on carbon and water budgets in evergreen needleleaf forests. Agricultural and Forest Meteorology, 113, 185-222.

Thornton, P.E., Doney, S.C., Lindsay, K., Moore, J.K., Mahowald, N., Randerson, J.T., Fung, I., Lamarque, J.F., Feddema, J.J., Lee, Y.H., 2009. Carbon-nitrogen interactions regulate climate-carbon cycle feedbacks: results from an atmosphere-ocean general circulation model. Biogeosciences 6, 2099-2120.

Tomppo, E., 1991, Satellite image-based National Forest Inventory of Finland. Proceedings of the symposium on global and environmental monitoring, techniques and impacts, Victoria, British Columbia, Canada, 17-21, September 1990. International Archives of Photogrammetry and Remote Sensing, Vol. 28, 419-424.

Townsend, P. A., Singh, A., Foster, J. R., Rehberg, N. J., Kingdon, C. C., Eshleman, K. N., and Seagle, S. W., 2012, A general Landsat model to predict canopy defoliation in broadleaf deciduous forests. Remote Sensing of Environment, 119:255-265.

Treuhaft, R.N., Law, B.E., and Asner, G.P., 2004, Forest attributes from radar interferometric structure and its fusion with optical remote sensing, Bioscience, 54, 561-571.

Treuhaft, R.N., Goncalves, F., dos Santos, J.R., Keller, M.Palace, M., Madsen. S.N., Sullivan, F., Graca, P.M.L.A., 2015, Tropical-forest biomass estimation at X-band from the Spaceborne TanDEM-X Interferometer, IEEE Geoscience and Remote Sensing Letters, $12,239-243$. 
Tucker, C. J., 1979, Red and photographic infrared linear combinations for monitoring vegetation. Remote Sensing of Environment, 8, 127-150.

Tucker, C.J., J.R.G. Townshend, and T.E. Goff, 1985, African land-cover classification using satellite data, Science 227, 369-375.

Turner, D.P., Jacobson, A.R., Ritts, W.D., Wang, W.L., Nemani, R., 2013. A large proportion of North American net ecosystem production is offset by emissions from harvested products, river/stream evasion, and biomass burning. Global Change Biology, 19, 35163528.

Turner, D.P., Ollinger, S.V., Kimball, J.S., 2004, Integrating remote sensing and ecosystem process models for landscape- to regional-scale analysis of the carbon cycle. Bioscience $54,573-584$.

Turner, D. P., Ritts, W. D., Cohen, W. B., Gower, S. T., Running, S. W., Zhao, M., Costa, M. H., Kirschbaum, A. A., Ham, J. M., Saleska, S. R. \& Ahl, D. E., 2006, Evaluation of MODIS NPP and GPP products across multiple biomes. Remote Sensing of Environment, 102, 282-292.

Turner, D.P., Ritts, W.D., Styles, J.M., Yang, Z., Cohen, W.B., Law, B.E., Thornton, P.E., 2006. A diagnostic carbon flux model to monitor the effects of disturbance and interannual variation in climate on regional NEP. Tellus B 58, 476-490.

Turner, D.P., Ritts, W.D., Yang, Z., Kennedy, R.E., Cohen, W.B., Duane, M.V., Thornton, P.E., Law, B.E., 2011, Decadal trends in net ecosystem production and net ecosystem carbon balance for a regional socioecological system. Forest Ecology and Management $262,1318-1325$.

Ustin, S.L., Gitelson, A.A., Jacquemoud, S., Schaepman, M., Asner, G.P., Gamon, J.A., and Zarco-Tejada, P., 2009, Retrieval of foliar information about plant pigment systems from high resolution spectroscopy. Remote Sensing of Environment, 113,S67-S77.

van der Tol, C., Berry, J.A., Campbell, P.K.E. and Rascher, U., 2015, Models of fluorescence and photosynthesis for interpreting measurements of solar-induced chlorophyll fluorescence : open access. Journal of Geophysical Research -Biogeosciences, 119, DOI: $10.1002 / 2014 J G 002713$. 
van der Werf, G.R., Randerson, J.T., Collatz, G.J., Giglio, L., Kasibhatla, P.S., Arellano, A.F., Olsen, S.C., Kasischke, E.S., 2004, Continental-Scale Partitioning of Fire Emissions During the 1997 to 2001 El Niño/La Niña Period. Science 303, 73-76.

van der Werf, GR, Morton, DC, DeFries, RS, Giglio, L, Randerson, JT, Collatz, GJ, Kasibhatla, PS, 2009, Estimates of fire emissions from an active deforestation region in the southern Amazon based on satellite data and biogeochemical modelling, Biogeosciences, 6, doi:10.1016/j.atmosenv.2008.09.047.

van Wagtendonk, J. W., Root, R. R., and Key, C. H., 2004, Comparison of AVIRIS and Landsat ETM+ detection capabilities for burn severity. Remote Sensing of Environment, 92, 397-408

Vinukollu, R.K., Wood, E.F., Ferguson, C.R., and Fisher, J.B., 2011, Global estimates of evapotranspiration for climate studies using multi-sensor remote sensing data: Evaluation of three process-based approaches. Remote Sensing of Environment, 115, 801-823.

Vogelmann, J. E., Tolk, B., and Zhu, Z., 2009, Monitoring forest changes in the southwestern United States using multitemporal Landsat data. Remote Sensing of Environment, 113, $1739-1748$.

Waring, R. H., Law, B. E., Goulden, M. L., Bassow, S. L., McCreight, R. W., Wofsy, S. C. and Bazzaz, F. A., 1995, Scaling daytime gross ecosystem production at Harvard Forest with remote sensing: a comparison of estimates from a constrained quantum-use efficiency model and eddy correlation. Plant Cell and Environment, 18, 1201-1213.

Watts, A. C., Ambrosia, V. G., Hinkley, A. E., 2012, Unmanned Aircraft Systems in Remote Sensing and Scientific Research: Classification and Considerations of Use. Remote Sensing, 4, 1671-1692.

White, J. D., Ryan, K. C., Key, C. C., \& Running, S. W.,1996, Remote sensing of forest fire severity and vegetation recovery. International Journal of Wildland Fire, 6, 125-136.

Williams, C.A., Collatz, G.J., Masek, J.G., and Goward, S., 2012, Carbon consequences of forest disturbance and recovery across the conterminous United States, Global Biogeochemical Cycles, 26, 10.1029/2010GB003947 
Williams, C. A., Collatz, G. J., Masek, J., Huang, C., and Goward, S. N., 2014, Impacts of disturbance history on forest carbon stocks and fluxes: Merging satellite disturbance mapping with forest inventory data in a carbon cycle model framework. Remote Sensing of Environment.151, 57-71.

Wilson, E. H. and Sader, S. A., 2002, Detection of forest harvest type using multiple dates of Landsat TM imagery. Remote Sensing of Environment, 80, 385-396.

Wimberly, M. C., \& Reilly, M. J.,2007, Assessment of fire severity and species diversity in the southern Appalachians using Landsat TM and ETM+ imagery. Remote Sensing of Environment, 108, 189-197.

Wulder, M.A., White, J.C., Nelson, R.F., Naesset, E., Ørka, H.O., Coops, N.C., Hilker, T., Bater, C.W., \& Gobakken, T. (2012). Lidar sampling for large-area forest characterization: A review. Remote Sensing of Environment, 121, 196-209

Wullschleger, S.D., Epstein, H.E., Box, E.O., Euskirchen, E.S., Goswami, S., Iversen, C.M., Kattge, J., Norby, R.J., van Bodegom, P.M., Xu, X., 2014, Plant functional types in Earth system models: past experiences and future directions for application of dynamic vegetation models in high-latitude ecosystems. Annals of Botany 114, 1-16.

Zald, H.S.J., Ohmann, J.L., Roberts, H.M., Gregory, M.J., Henderson, E.B., McGaughey, R.J., Braaten, J., 2014, Influence of lidar, Landsat imagery, disturbance history, plot location accuracy, and plot size on accuracy of imputation maps of forest composition and structure. Remote Sensing of Environment 143, 26-38.

Zeng, N., Mariotti, A., Wetzel, P., 2005, Terrestrial mechanisms of interannual CO2 variability. Global Biogeochem Cycles, 19, GB1016.

Zhang, F., Chen, J. M., Pan, Y., Birdsey, R. A., Shen, S., Ju, W., and He, L., 2012, Attributing carbon changes in conterminous U.S. forests to disturbance and non-disturbance factors from 1901 to 2010. Journal of Geophysical Research: Biogeosciences, 117(G2).

Zhang, K., Kimball, J. S., Zhao, M. S., Oechel, W. C., Cassano, J. \& Running, S. W., 2007, Sensitivity of pan-Arctic terrestrial net primary productivity simulations to daily surface meteorology from NCEP-NCAR and ERA-40 reanalyses. Journal of Geophysical Research-Biogeosciences, 112, 14. 
Zhao, M. S. \& Running, S. W., 2010, Drought-induced reduction in global terrestrial net primary production from 2000 through 2009. Science, 329, 940-943.

Zhu, Z., Woodcock, C. E., and Olofsson, P., 2012, Continuous Monitoring of Forest

Disturbance Using All Available Landsat Imagery, Remote Sensing of Environment, 122, $75-91$

Zolkos, S., Goetz, S.J., \& Dubayah , R.O., 2013. A meta-analysis of terrestrial above-ground biomass estimation using lidar remote sensing. Remote Sensing of Environment, 128, 289-298. 


\section{Figure Captions}

Figure 1. Key variables needed to scale ecosystem studies or parameterize process models, and the relevant remote sensing approaches for their retrieval. Remote sensing modalities (passive optical, radar, etc) are shown in the left column together with common sensor examples. Green=modality is strongly relevant for retrieving variable; yellow=modality can support variable retrieval, subject to limitations in accuracy. Note that additional geographic and temporal limitations may limit application (e.g. the lack of a global hyperspectral system limits the ability to retrieve canopy pigments globally, despite the relevance of the technology).

Figure 2. Example of airborne lidar canopy height measurements from the Parker Tract, North Carolina, using the NASA Goddard's Lidar, Hyperspectral, and Thermal (GLiHT) instrument package (Cook et al., 2013). The site consists of a mosaic of planted loblolly pine with known stand age (a-c), as well as patches of older, unmanaged forest (d). Indications of management practice (row planting, strip thinning) are visible in the insets a-c.

Figure 3. Anthropogenic and natural disturbances can be characterized across a press - pulse spectrum in terms of the spatial and temporal scale of their impact on managed forests. The choice of the spatial and temporal scale of remote sensing data used to detect and characterize different disturbance types varies with these press-pulse characteristics. 
Figure 4. Disturbances shape all landscapes, and human activity can cause significant differences in forest structure and composition across ownership boundaries. Time series of Landsat imagery are useful for identifying the cumulative impact of human activity; Landsat was used to map clearcut harvests over three ownership classes on the Olympic Peninsula, Washington 


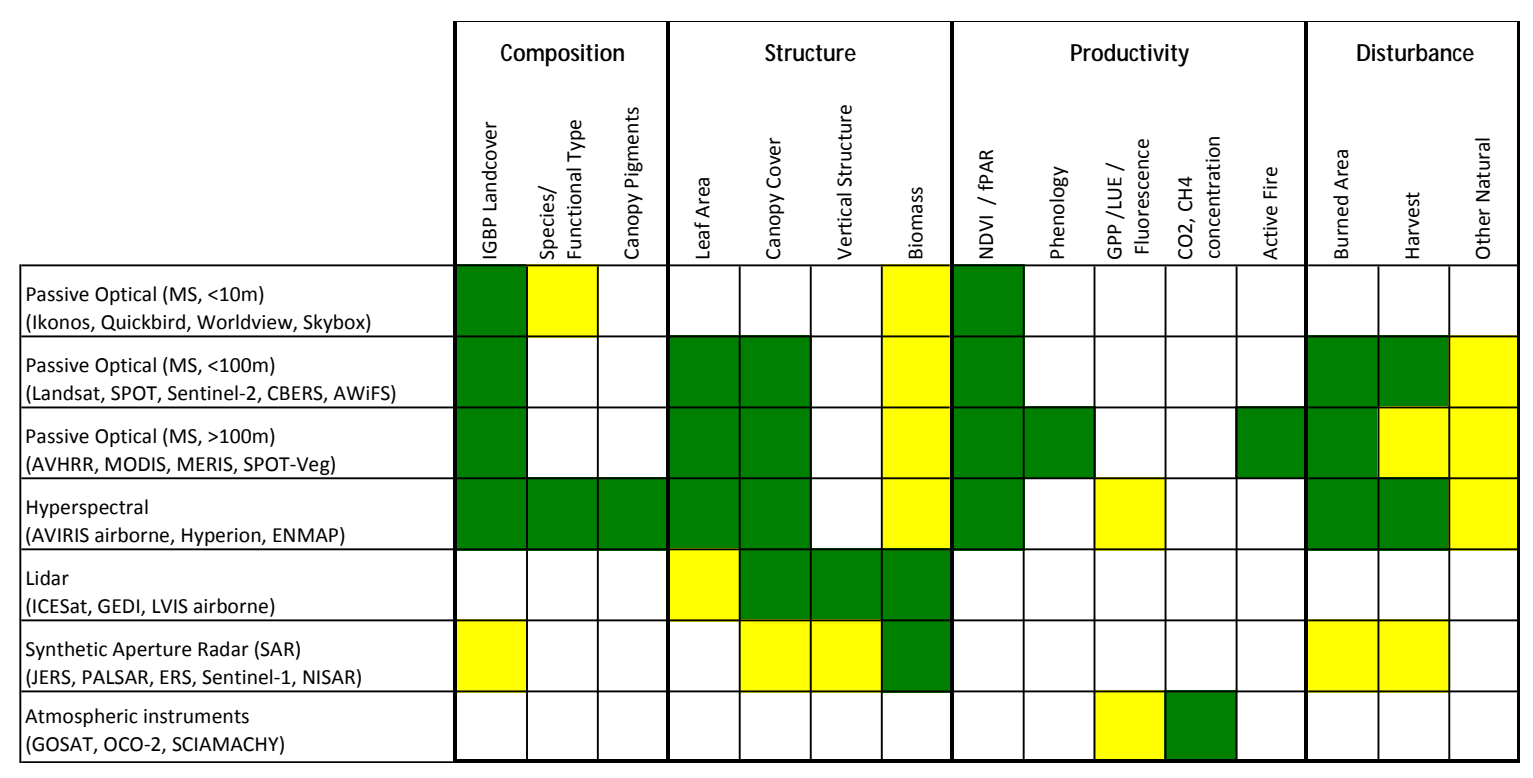

Fig. 1 


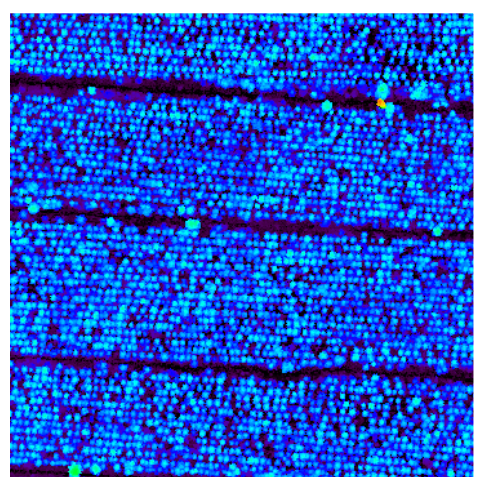

(a) $10 y$

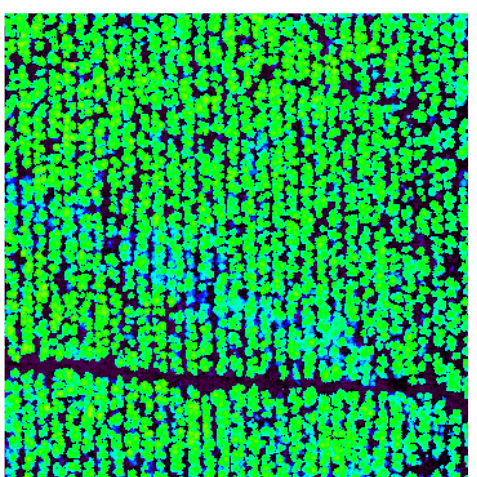

(b) $21 \mathrm{y}$

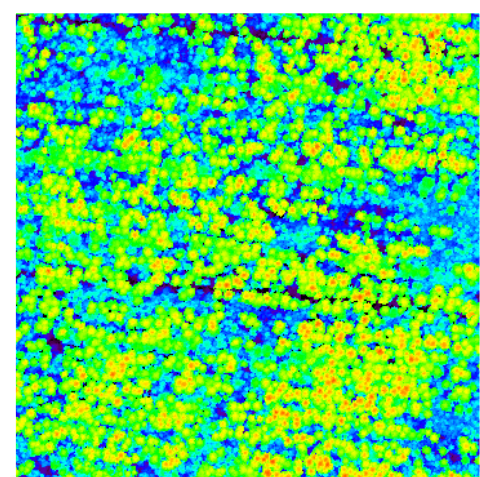

(c) $29 \mathrm{y}$

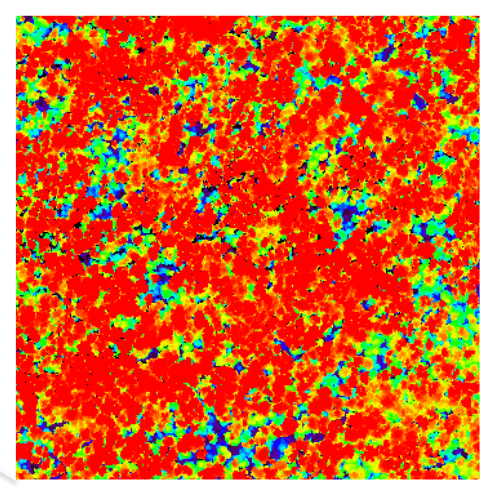

(d) Mature (Reserved)

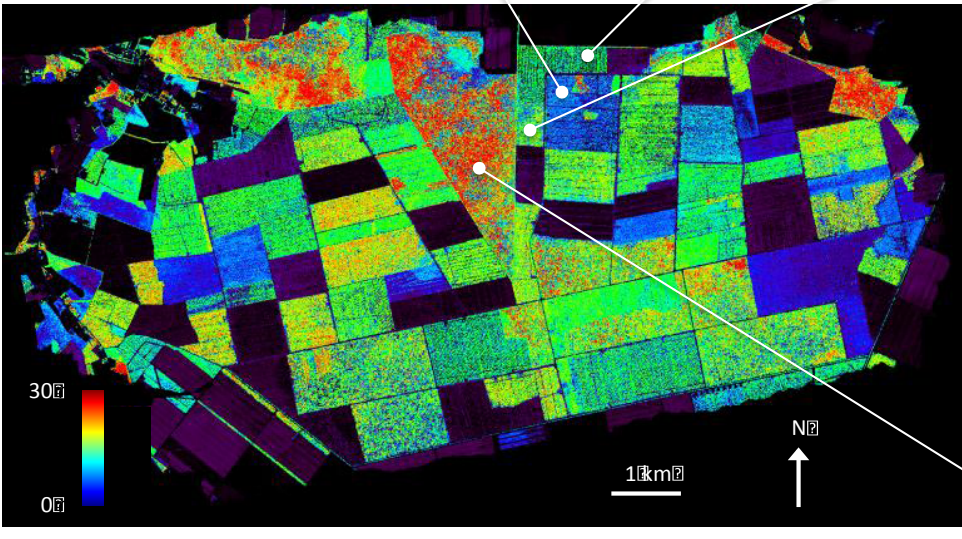

Fig. 2 


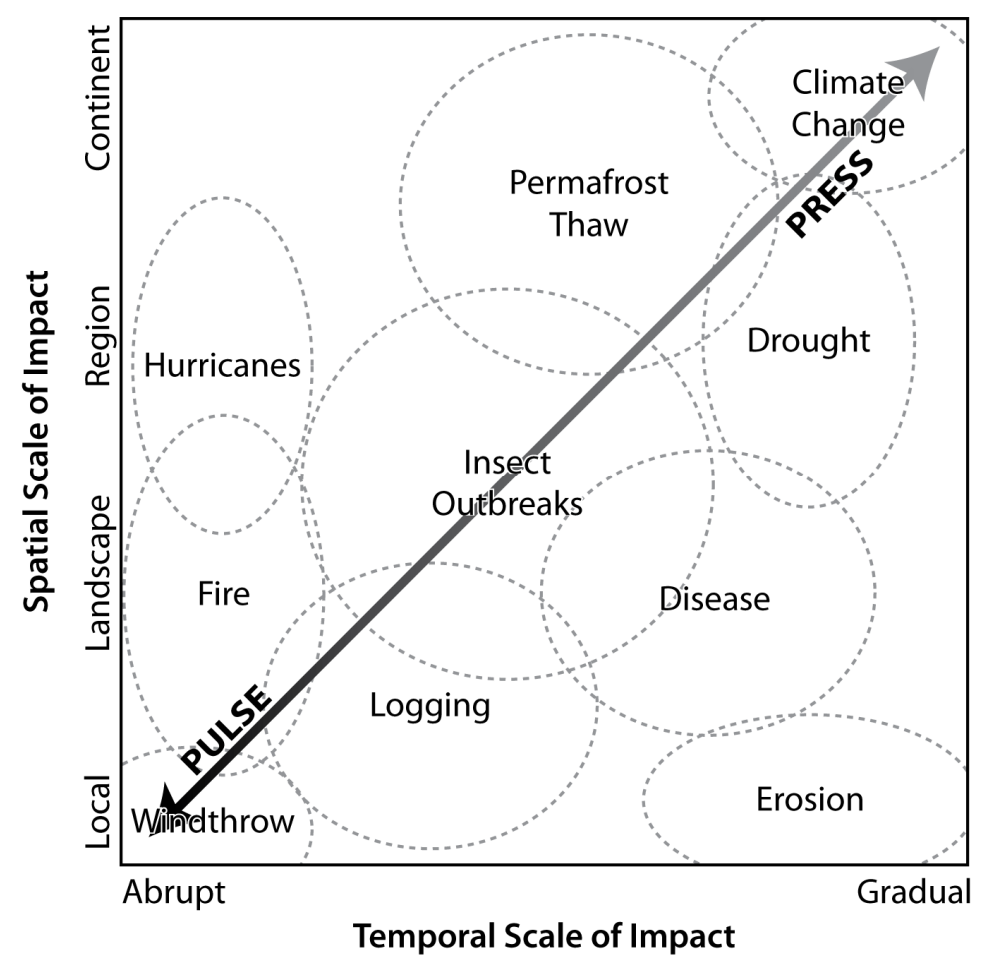

Fig. 3 


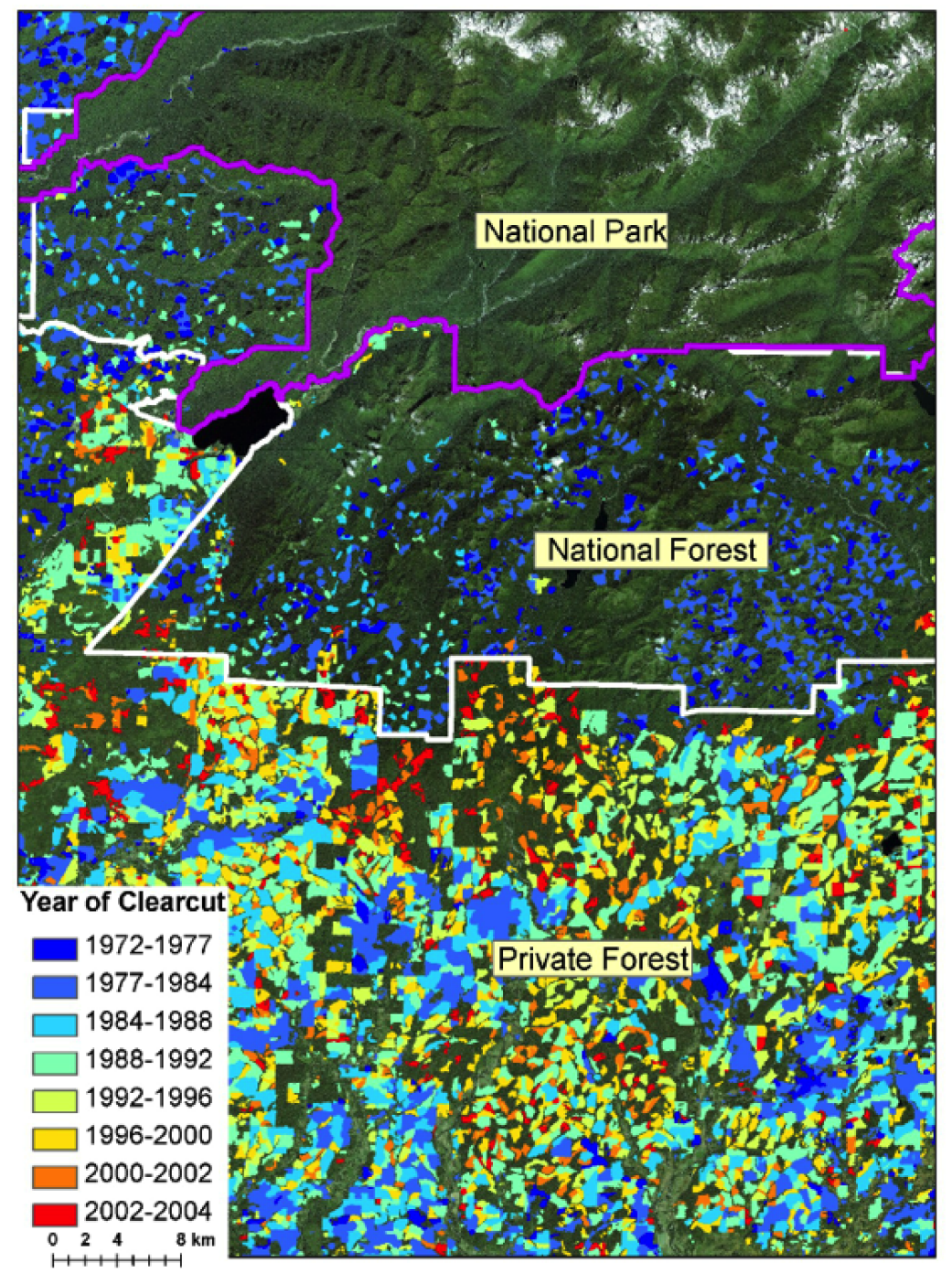

Fig. 4. 